\title{
Recent Progress in Trivalent Actinide and Lanthanide Solvent Extraction and Coordination Chemistry with Triazinylpyridine N-Donor Ligands
}

\author{
Andreas Geist ${ }^{\mathrm{a}}$ and Petra J. Panak ${ }^{\mathrm{a}, \mathrm{b}}$ \\ ${ }^{a}$ Karlsruhe Institute of Technology (KIT), Institute for Nuclear Waste Disposal (INE), \\ Karlsruhe, Germany \\ ${ }^{b}$ Physikalisch Chemisches Institut (PCI), Ruprecht-Karls-Universität Heidelberg, \\ Heidelberg, Germany
}

\begin{abstract}
A follow up to an earlier review on the coordination and extraction of trivalent actinide and lanthanide ions with triazinylpyridine $\mathrm{N}$-donor ligands is presented. It reviews the recent development in the fields of ligand modifications and improvements, considering both hydrophobic compounds (to be used as extracting agents) and hydrophilic compounds (to be used as stripping agents), with a focus on fundamental studies.
\end{abstract}

\section{Introduction}

For more than 50 years, Renato Chiarizia had inspired the Solvent Extraction and Actinide Separations community, both as a scientist and as a long-time Editor of Solvent Extraction \& Ion Exchange. The separation of trivalent "minor" actinides is one of the numerous fields he was interested in. ${ }^{1-6}$ Working in this field, too (albeit using different chemistry), we feel honoured for having been invited to contributing to this special issue of Solvent Extraction and Ion Exchange in memory of Renato. We hope he would have enjoyed reading our contribution.

In 2012 we reviewed the complexation and extraction of trivalent actinides, An(III), and lanthanides, Ln(III) by bis-triazinyl-(bi)pyridine N-donor ligands. ${ }^{7}$ Such ligands play a central role in the development of solvent extraction processes aimed at separating An(III) from irradiated nuclear fuels. ${ }^{8}$ Ligand design ultimately must keep applicability in mind. With this, among the major constraints are compatibility (i. e. sufficient solubility of both the ligand and the formed complexes in appropriate media), selectivity (more is better; however, even a separation factor of $\approx 2$ is sufficient to design a separation process), affinity (equilibria must be easily reversible - too high distribution ratios impede stripping), kinetics (obviously, faster is better), chemical and radiolytic stability. 
Indeed, alkylated bis-triazinyl pyridines (known as BTP, Figure 1 left) were the first extracting agents to extract $\mathrm{Am}(\mathrm{III})$ and $\mathrm{Cm}(\mathrm{III})$ selectively over $\mathrm{Ln}(\mathrm{III})$ out of solutions containing approximately molar nitric acid. ${ }^{9-10}$
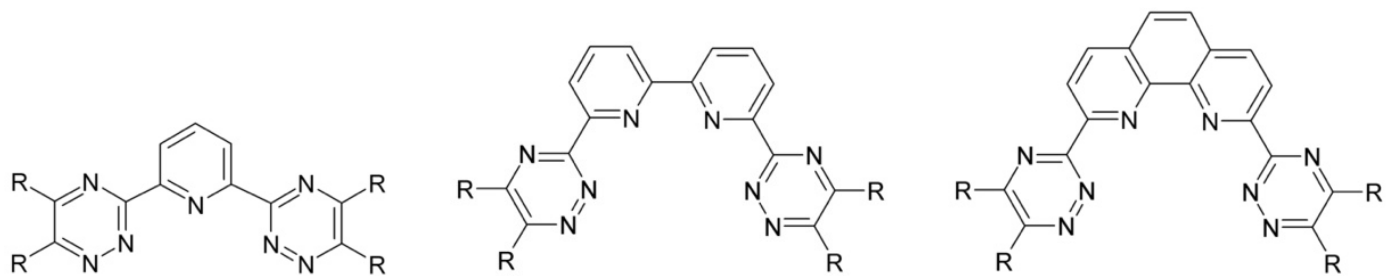

Figure 1. Generic BTP (left), BTBP (centre), and BTPhen (right) structures.

The first BTP compounds unfortunately were easily degraded by nitric acid and by radiation. The development leading to 6,6'-bis(5,5,8,8-tetramethyl-5,6,7,8-tetrahydro-benzo-1,2,4triazin-3-yl)-2,2'-bipyridine (CyMe $4-B T B P$, Figure 2), ${ }^{11-12}$ the European reference compound for $\mathrm{An}(\mathrm{III}) / \mathrm{Ln}(\mathrm{III})$ separations to date, is reviewed in the literature in due detail., ${ }^{73-16}$

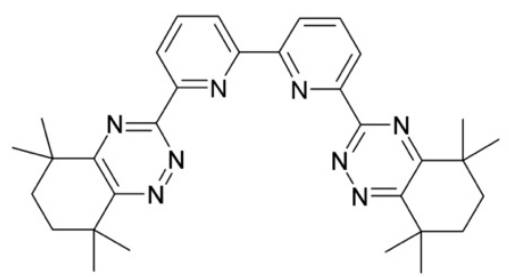

Figure 2. Molecular structure of $\mathrm{CyMe}_{4}-\mathrm{BTBP}$.

Covering the period from 2013 onwards, the present review gives an update on BTP, BTBP, and BTPhen (Figure 1) compounds (including some promising modifications to the backbone) relating to $\mathrm{An}(\mathrm{III}) / \mathrm{Ln}(\mathrm{III})$ separations. We explicitly do not review the literature on solid-state structures, ${ }^{17-18}$ solvent extraction process development, ${ }^{19-30}$ solid-liquid applications, ${ }^{31-40}$ radiolysis and stability studies, ${ }^{41-50}$ non-An(III)-Ln(III) chemistry, ${ }^{51-56}$ and theory studies.${ }^{57-66}$

A sound knowledge of their coordination chemistry is instrumental to designing improved extracting and complexing agents. Thus, this article reviews the recent literature on $\mathrm{An}(\mathrm{III}) / \mathrm{Ln}(\mathrm{III})$ solvent extraction and coordination chemistry with the above-mentioned ligands, highlights current trends, and proposes directions to proceed. Finally, this article also reflects the authors' views. 


\section{Systematic modifications to hydrophobic BTP and BTBP ligands}

To optimize their properties as extracting agents, structural modifications were carried out on BTP and BTBP ligands. Recent modifications include variations to the substituents at the triazines $^{67}$ or the substituents on the pyridine ring. ${ }^{68-69}$ 2,6-bis(5,6,7,8-tetrahydro-5,9,9trimethyl-5,8-methano-1,2,4-benzotriazin- 3-yl)pyridine (CA-BTP, Figure 3 top left) ${ }^{70}$ was further studied, extending to further diluents. ${ }^{71}$ CA-BTP however is not further studied in Europe due to problems with scale-up of the synthesis, i. e. the production of larger batches with reproducible properties.

So far, ligands foregoing the basic triazine-(bi)pyridine-triazine structure (e.g., 2,6-bis(1,2,4triazol-3-yl)pyridines (Figure 3 bottom left), ${ }^{9}$ 2,6-bis(pyrazol-3-yl)pyridines (Figure 3 bottom right), ${ }^{72}$ and others ${ }^{73-74}$ ) did not extract An(III) nitrates, requiring addition of a lipophilic anion source such as 2-bromohexanoic acid.

Based on the favourable complexing properties of the water-soluble ligand PyTri-Diol (see section PyTri-Diol below and references ${ }^{75-76}$ ), several lipophilic derivatives were synthesised and tested. Of these, 2,6-bis[1-(2-ethylhexyl)-1,2,3-triazol-4-yl]pyridine (PTEH, Figure 3 top right) dissolved in kerosene/1-octanol mixtures extracts $\mathrm{Am}$ (III) directly (i. e., without requiring the addition of 2-bromohexanoic acid) from 1-4 mol/ $\mathrm{L} \mathrm{HNO}_{3}$, separating it from $\mathrm{Eu}(\mathrm{IIII})\left(S F_{\mathrm{Am}(\mathrm{III}) \mathrm{Eu}(\mathrm{III})}=70-100\right) .^{77}$
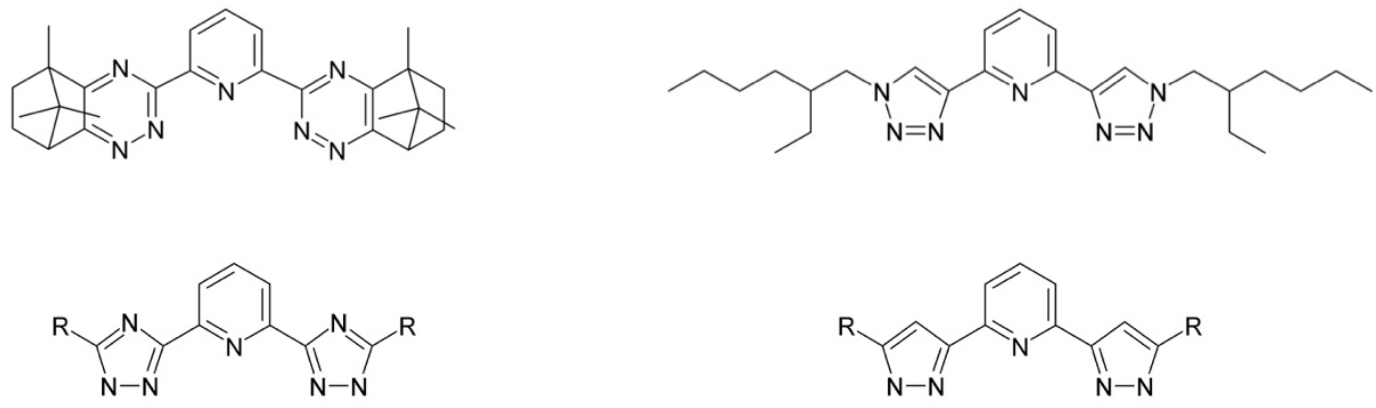

Figure 3. Molecular structures of CA-BTP (top left), PTEH (top right), 2,6-bis(1,2,4-triazol-3-yl)pyridines (bottom left), and 2,6-bis(pyrazol-3-yl)pyridines (bottom right).

Furthermore, the influence of the number of aromatic nitrogen atoms in the lateral rings on complexation properties was studied. In this context, two remarkable studies have to be mentioned. These show that theoretical predictions ${ }^{78}$ are not necessarily confirmed by experiment. ${ }^{79}$

Density functional theory was used to evaluate fundamental properties (intrinsic binding affinity for $\mathrm{Ln}(\mathrm{III})$, basicity, and hardness) for prototype azine donors pyridine, pyridazine, 
pyrimidine, pyrazine, 1,2,3-triazine, 1,2,4-triazine, and 1,3,5-triazine. ${ }^{78}$ The calculations showed pyridazine having the strongest intrinsic affinity for metal ions and being the second softest donor. Based on this information, three new prototype compositions of different azines were proposed which should exhibit improved metal ion affinity and An(III)/Ln(III) selectivity: pyridazine-pyridine-pyridazine, pyridazine-pyrazine-pyridazine, and pyridazine-1,3,5-triazinepyridazine.

To obtain experimental evidence of these predictions two BTP-type N-donor ligands with different numbers of aromatic nitrogen atoms were synthesized and studied: 2,6-bis(4-ethylpyridazin-1-yl)pyridine (Et-BDP, a pyridazine-pyridine-pyridazine) and 2,6-bis(4-propyl2,3,5,6-tetrazin-1-yl)pyridine (nPr-tetrazine), see Figure 4. Their complexation properties towards $\mathrm{Cm}$ (III) in 2-propanol-water (1:1, vol.) were compared to that of nPr-BTP (Figure 1 left, $\mathrm{R}=$ propyl) in the same solvent. ${ }^{79}$
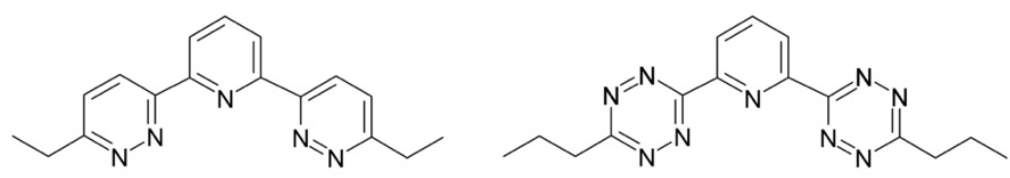

Figure 4. Molecular structures of Et-BDP (left) and nPr-tetrazine (right).

Speciation studies using time-resolved fluorescence spectroscopy (TRLFS) showed both EtBDP and nPr-tetrazine to form 1:1, 1:2, and 1:3 complexes with $\mathrm{Cm}(\mathrm{III})$, whereas in case of nPr-BTP the 1:3 complex is formed exclusively. The conditional stability constants of the 1:3 complexes in 2-propanol/water (1:1, vol.) increase in the order $\lg \beta_{3}\left[\mathrm{Cm}(\mathrm{Et}-\mathrm{BDP})_{3}\right]=7.7 \pm$ $0.3, \lg \beta_{3}\left[\mathrm{Cm}(\mathrm{nPr}-\text { Tetrazine })_{3}\right]=9.1 \pm 0.4$ and $\lg \beta_{3}\left[\mathrm{Cm}(\mathrm{nPr}-\mathrm{BTP})_{3}\right]=12.9 \pm 0.3$. Hence, the complexation of $\mathrm{Cm}$ (III) with both ligands is thermodynamically less favoured than the formation of $\left[\mathrm{Cm}(\mathrm{nPr}-\mathrm{BTP})_{3}\right]$. A similar trend was observed in solvent extraction tests: ${ }^{73}$ Both Et-BDP and nPr-Tetrazine hardly extract any Am(III) and Eu(III) from solutions containing $>0.1 \mathrm{~mol} / \mathrm{L} \mathrm{HNO}_{3}$. In contrast to the theoretical predictions, ${ }^{78}$ the $1,2,4$-triazine substituent was found to represent a structural optimum regarding complexation and solvent extraction performance.

\section{Stability constants of An(III)-BTP and An(III)-BTBP complexes}

A wealth of conditional stability constants for the complexation of $\operatorname{Ln}(\mathrm{III})$ with BTP and BTBP ligands is summarized in our previous review article, ${ }^{7}$ together with few constants for An(III).

New stability constants were determined for $\left[\mathrm{Am}(\mathrm{BTP})_{3}\right]^{3+} 80$ and $\left[\mathrm{Am}(\mathrm{BTBP})_{2}\right]^{3+}$ complexes $^{81}$ in acetonitrile $+0.01 \mathrm{~mol} / \mathrm{L}$ tetramethylammonium nitrate. The values are in good agreement 
with stability constants for the respective Cm(III) complexes, ${ }^{82-85}$ considering that different solvents (alcohol-water mixtures) were used.

To better understand the effect of solvent composition on stability constant values, a systematic investigation on the complexation of $\mathrm{Cm}$ (III) and $\mathrm{Eu}(\mathrm{III})$ with $\mathrm{nPr}$-BTP in methanol/water mixtures (5-50 vol\% water) using TRLFS was performed. ${ }^{84}$ The stability constant of the $\left[\mathrm{Cm}(\mathrm{nPr}-\mathrm{BTP})_{3}\right]^{3+}$ complex was shown to increase by three orders of magnitude when the water content was reduced from $50 \mathrm{vol} \%\left(\lg \beta_{3}=14.3 \pm 0.1\right)$ to $5 \mathrm{vol} \%\left(\lg \beta_{3}=17.4 \pm 0.4\right)$. Only a slight increase was observed between $50 \mathrm{vol} \%$ and $20 \mathrm{vol} \%$ due to the preferential solvation of $\mathrm{Cm}$ (III) by water; ${ }^{86}$ the increase was more pronounced for water contents between $20 \mathrm{vol} \%$ and $5 \mathrm{vol} \%$. A similar trend was observed for the stability constant of the $\left[\mathrm{Eu}(\mathrm{nPr}-\mathrm{BTP})_{3}\right]^{3+}$ complex $\left(\lg \beta_{3}=12.0 \pm 0.1\right.$ at $50 \mathrm{vol} \%$ water content; $\lg \beta_{3}=14.7 \pm 0.4$ at $5 \mathrm{vol} \%$ water content $)$, resulting in a constant difference between the stability constants of the $\mathrm{Cm}$ (III) and $\mathrm{Eu}(\mathrm{III}) 1: 3$ complexes $\left(\Delta \lg \beta_{3} \approx 2.3\right.$, see Figure 5).

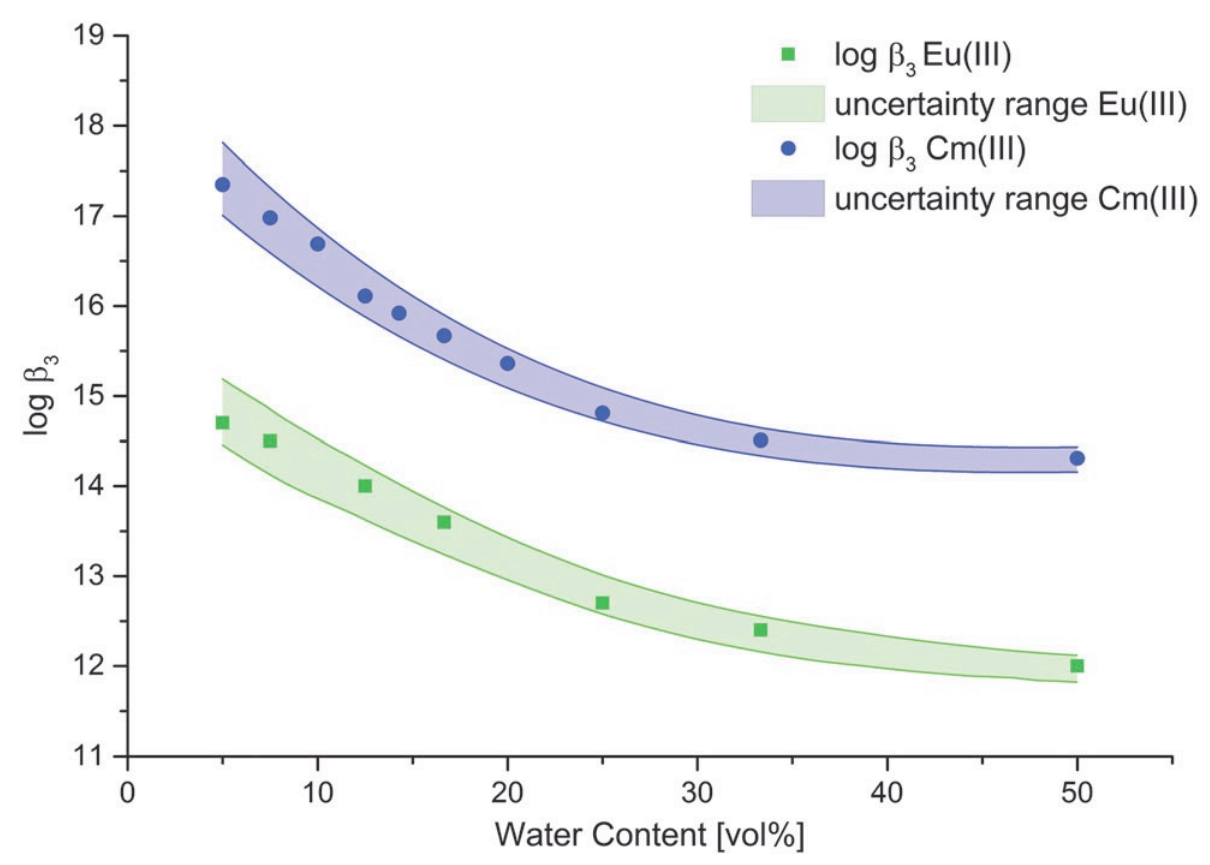

Figure 5. Stability constants of $\left[\mathrm{Cm}(\mathrm{nPr}-\mathrm{BTP})_{3}\right]^{3+}$ and $\left[\mathrm{Eu}(\mathrm{nPr}-\mathrm{BTP})_{3}\right]^{3+}$ as a function of the water content in methanol-water mixtures (water content, $5-50 \mathrm{vol} \%, \mathrm{c}\left(\mathrm{Cm}(\mathrm{III})_{\mathrm{ini}}=10^{-7} \mathrm{~mol} / \mathrm{L}, \mathrm{c}(\mathrm{Eu}(\mathrm{III}))_{\text {ini }}=10^{-5} \mathrm{~mol} / \mathrm{L}\right.$, $\left.\mathrm{c}\left(\mathrm{H}^{+}\right)=10 \mathrm{mmol} / \mathrm{L}\right)$. Reproduced from reference ${ }^{84}$ by permission of The Royal Society of Chemistry (RSC) on behalf of the Centre National de la Recherche Scientifique (CNRS) and the RSC.

These results demonstrate the strong impact of the solvent on a ligand's complexation strength as evident from the changes of the stability constants, whereas the selectivity remained constant for all solvent mixtures investigated. 


\section{Update on NMR investigations}

Speciation studies by NMR including ${ }^{1} \mathrm{H}-\mathrm{NMR}$ titrations and relaxation titrations have been performed to determine the species distribution and complex stoichiometry of An(III) and Ln(III) with BTP, BTBP and BTPhen ${ }^{11,87-95}$ in solution.

In addition, comparative NMR studies on Am(III) and Ln(III) with BTP and similar ligands were performed to obtain further information on the molecular origin of the selectivity of Ndonor ligands. In particular, ${ }^{15} \mathrm{~N}$ NMR spectroscopy using ${ }^{15} \mathrm{~N}$-enriched ligands gave detailed insight into the bonding of $\mathrm{N}$-donor ligands with $\mathrm{Am}(\mathrm{III})$ and $\mathrm{Ln}(\mathrm{III}) .{ }^{15} \mathrm{~N}$ signals from coordinating $\mathrm{N}$-atoms in the $\mathrm{Am}(\mathrm{III})$ complexes were shifted upfield by $\approx 300 \mathrm{ppm}$ in comparison both to Ln(III) complexes and to the free ligand (see Figure 6). ${ }^{96-97}$ Furthermore, a slight temperature dependence of the chemical shifts of NMR resonance signals of the Am(III) complexes was observed, indicating a weak paramagnetism of Am(III). This shows that metalligand bonding in $\left[\mathrm{Am}(\mathrm{BTP})_{3}\right]^{3+}$ has a larger share of covalence than in the respective $\mathrm{Ln}(\mathrm{III})$ complexes. Comparable upfield shifts of the ${ }^{15} \mathrm{~N}$ signals of the coordinating $\mathrm{N}$ atoms were also observed for the $\left[\mathrm{Am}(\mathrm{C} 5-\mathrm{BPP})_{3}\right]^{3+}$ complex (C5-BPP $=$ 2,6-bis(5-(2,2-dimethylpropyl)pyrazol-3-yl)pyridine, Figure 3 bottom right, $\mathrm{R}=2$,2-dimethylpropyl), ${ }^{98}$ confirming significant differences in the bonding of Am(III) and Ln(III) complexes with N-donor ligands in general.

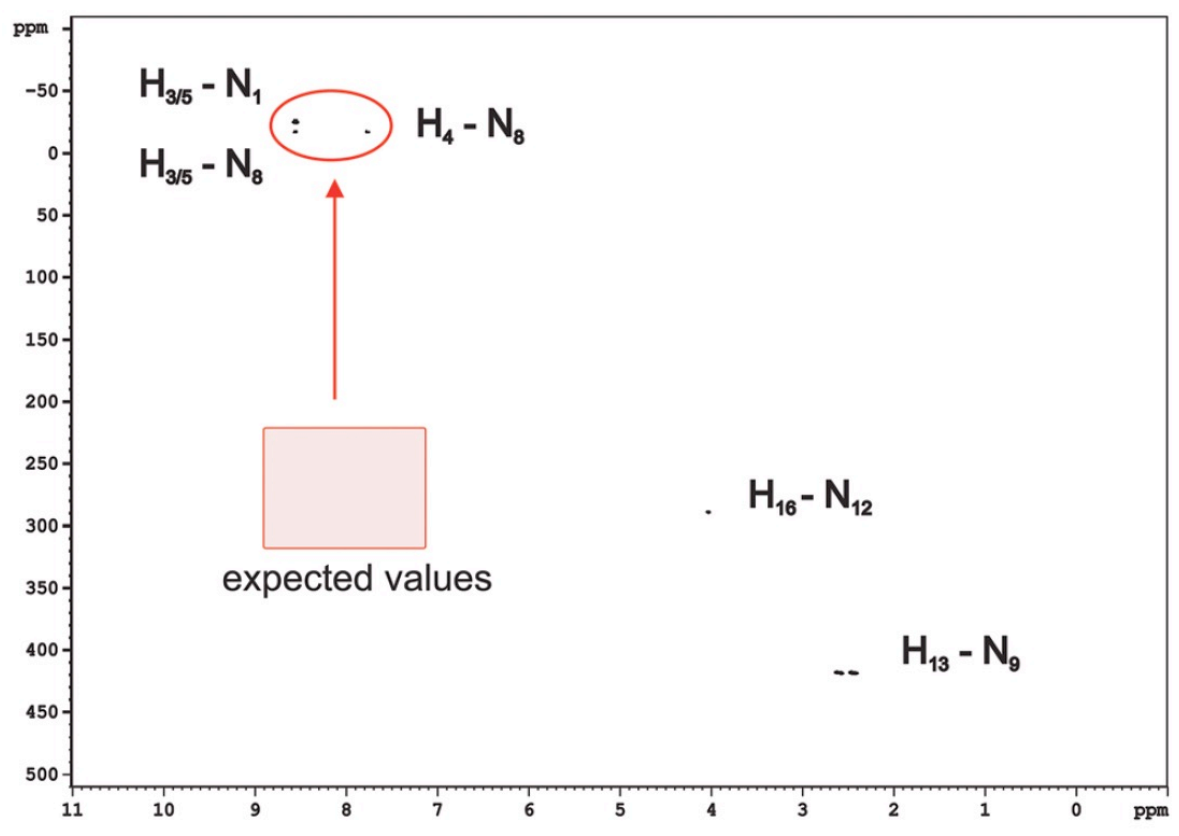

Figure 6. Overlay of two ${ }^{1} \mathrm{H},{ }^{15} \mathrm{~N}-\mathrm{HMQC}$ spectra of ${ }^{243} \mathrm{Am}(\mathrm{III})$ complexed with unlabelled and $10 \%$ labelled nPr-BTP (MeOD- $\mathrm{d}_{4}$ and $\mathrm{D}_{2} \mathrm{O} 3: 1$ ) with ${ }^{\mathrm{n}} J_{\mathrm{HN}}$ of 5 and $2 \mathrm{~Hz}$, respectively. The "expected values" range is taken from similar experiments with pure ligand and Lu(III) and Sm(III) complexes. Reproduced from reference ${ }^{96}$ by permission of The Royal Society of Chemistry. 


\section{BTPhen compounds}

As an alternative to $\mathrm{CyMe}_{4}-\mathrm{BTBP}, \mathrm{CyMe}_{4}-\mathrm{BTPhen}$ had been introduced. ${ }^{99}$ The BTPhen backbone is pre-organized in the cis conformation required for complexation and extraction while BTBP must overcome a rotational energy barrier prior to complexation. This was expected to result in improved properties as an extracting agent.

Indeed, this modification resulted in drastically changed properties: CyMe 4 -BTPhen actually is a too strong extracting agent, showing significant co-extraction of $\operatorname{Ln}($ III) and impeding backextraction. Consequently, numerous studies were performed to understand and improve its performance..$^{58,85,92-93,95,100-111}$ The following conclusions are drawn:

- The fact that BTPhen are stronger extracting agents for An(III) and Ln(III) is caused by differences in complex stability as evident from displacement experiments performed by $\mathrm{NMR}^{93}$ and stability constants determined by TRLFS. ${ }^{85}$

- Distribution ratios are repressed by electronically modifying the BTPhen, ${ }^{92,101,103-104}$ by adding TEDGA (a competing water soluble ligand), ${ }^{106}$ by changing the diluent ${ }^{99}$ or using ionic liquids as diluents, ${ }^{107,111}$ or by tuning the aliphatic ring size. ${ }^{95}$

- Increased $\mathrm{Am}(\mathrm{III}) / \mathrm{Cm}$ (III) selectivity and different intra-Ln(III) selectivity patterns for BTPhen $^{99}$ compared to BTBP ${ }^{12,112-113}$ are due to a kinetic effect. Upon extended contacting times, BTPhen show a selectivity similar to BTBP. ${ }^{104,108}$

Concluding, BTPhen fulfil the expectation of being stronger ligands compared to BTBP. However, bigger is not always better, and their performance as extracting agents to separate An(III) from Ln(III) indeed is inferior to that of the corresponding BTBP.

\section{Water soluble compounds}

\section{$\mathrm{SO}_{3}-\mathrm{Ph}-\mathrm{BTP}$}

A water soluble BTP, (2,6-bis(5,6-di(3-sulphophenyl)-1,2,4-triazin-3-yl)pyridine tetra-sodium salt, $\mathrm{SO}_{3}$-Ph-BTP, Figure 7 top left) ${ }^{114-116}$ was introduced to selectively strip An(III) from a solvent loaded with $\mathrm{An}(\mathrm{III})$ and $\mathrm{Ln}(\mathrm{III})$. This compound is an alternative to polyaminocarboxylates used in TALSPEAK-like processes. ${ }^{117}$ 


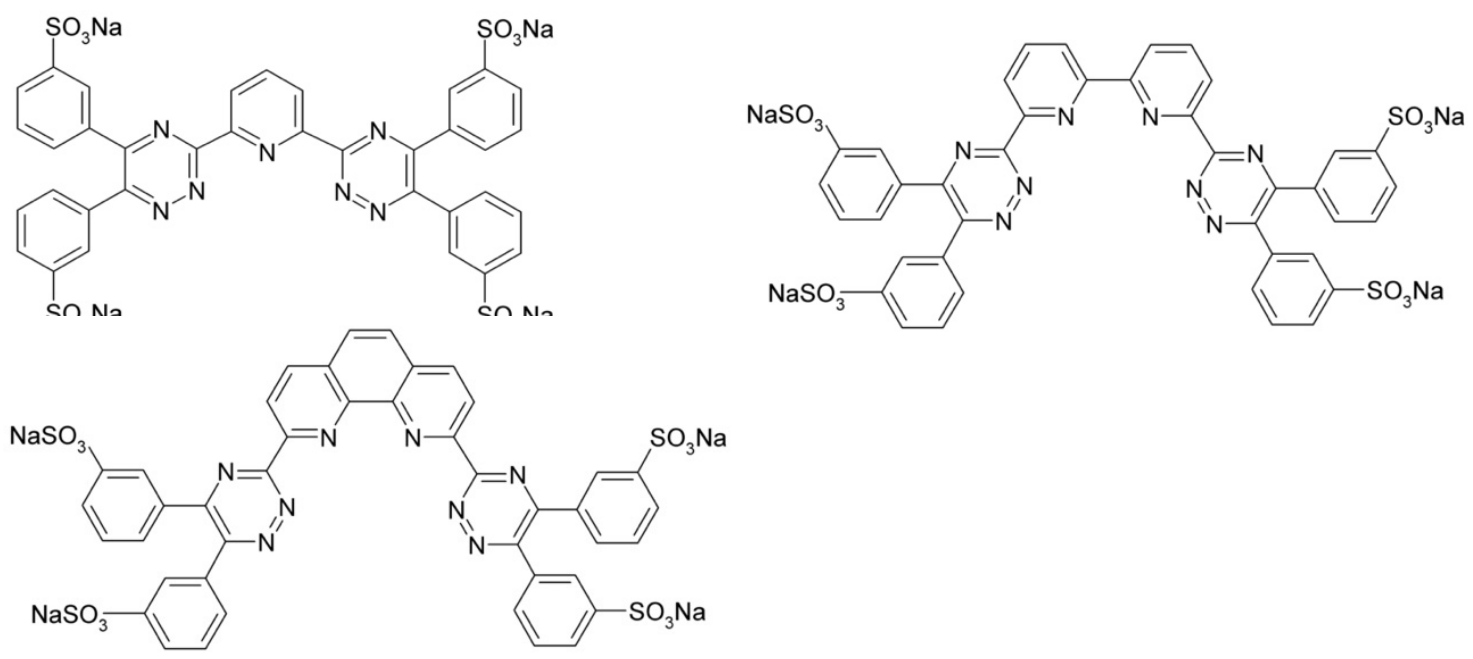

Figure 7. Molecular structures of $\mathrm{SO}_{3}-\mathrm{Ph}-\mathrm{BTP}$ (top left), $\mathrm{SO}_{3}-\mathrm{Ph}-\mathrm{BTBP}$ (top right), and $\mathrm{SO}_{3}-\mathrm{Ph}-\mathrm{BTPhen}$ (bottom).

A couple of recent publications illustrate this compound's impact on the development of $\mathrm{An}(\mathrm{III}) / \mathrm{Ln}(\mathrm{III})$ separation processes. Indeed, processes applying $\mathrm{SO}_{3}-\mathrm{Ph}-\mathrm{BTP}$ to generate an $\mathrm{Am}(\mathrm{III})+\mathrm{Cm}(\mathrm{III})$ product solution ${ }^{26}$ or a product solution containing $\mathrm{Np}, \mathrm{Pu}, \mathrm{Am}$ and $\mathrm{Cm}^{25}$ were demonstrated using laboratory scale centrifugal contactor equipment. The latter process (known as EURO-GANEX) was finally demonstrated successfully using a genuine high level feed solution. ${ }^{30}$ A product solution containing $\mathrm{Np}, \mathrm{Pu}, \mathrm{Am}$ and $\mathrm{Cm}$ with high purity was obtained, with recoveries of $\approx 99.9 \%$. A variation to the EURO-GANEX process, generating separate $\mathrm{Np}, \mathrm{Pu}$ and $\mathrm{Am}, \mathrm{Cm}$ product solutions, was also demonstrated. ${ }^{27}$

\section{$\mathrm{SO}_{3}-\mathrm{Ph}-\mathrm{BTBP}$}

Owing to the success achieved with $\mathrm{SO}_{3}-\mathrm{Ph}-\mathrm{BTP}$, sulphonated BTBP and BTPhen (only mentioned briefly in our previous review ${ }^{7}$ ) were further studied in more detail. ${ }^{118}$ A BTBP carrying two sulphophenyl moieties proved to be rather inefficient. However, BTBP and BTPhen with four sulphophenyl moieties had promising properties and were thus studied more deeply.

The solvent extraction properties of a system containing 6,6'-bis(5,6-di(3-sulphophenyl)-1,2,4triazin-3-yl)-2,2'-bipyridine tetra-sodium salt ( $\mathrm{SO}_{3}$-Ph-BTBP, Figure 7 top right) in the aqueous phase and $N, N, N^{\prime}, N^{\prime}$-tetra- $n$-octyl diglycolamide (TODGA) ${ }^{119-121}$ in the organic phase were studied in detail. ${ }^{122}$ Distribution ratios of Am(III), Cm(III) and $\mathrm{Ln}(\mathrm{III})$ were determined as a function of time and of nitric acid and $\mathrm{SO}_{3}-\mathrm{Ph}-\mathrm{BTBP}$ concentrations. It was expected that a TODGA/ $\mathrm{SO}_{3}$-Ph-BTBP solvent extraction system would separate Am(III) from $\mathrm{Cm}$ (III) and $\mathrm{Ln}(\mathrm{III})$, enabling the development of improved Am-only separation processes. ${ }^{123}$ As evident from Figure $8, D_{\mathrm{Am}(\mathrm{III})}<1$ and $D_{\mathrm{Cm}(\mathrm{III}), \mathrm{Ln}(\mathrm{III})}>1$ for $\left[H N O_{3}\right] \approx 0.8 \mathrm{~mol} / \mathrm{L}$, with $S F_{\mathrm{Cm}(\mathrm{III}) / \mathrm{Am}(\mathrm{III})}$ 
$\approx 2.5{ }^{122}$ This separation factor results from TODGA's selectivity for Cm(III) over Am(III), ${ }^{115}$ $S F_{\mathrm{Cm}(\mathrm{III}) / \mathrm{Am}(\mathrm{III})} \approx 1.6$, and a preferential affinity of BTBP for Am(III) over Cm(III), as observed e.g. for $\mathrm{CyMe}_{4}-\mathrm{BTBP},{ }^{12} S F_{\mathrm{Am}(\mathrm{III}) / \mathrm{Cm}(\mathrm{III})} \approx 1.6$.

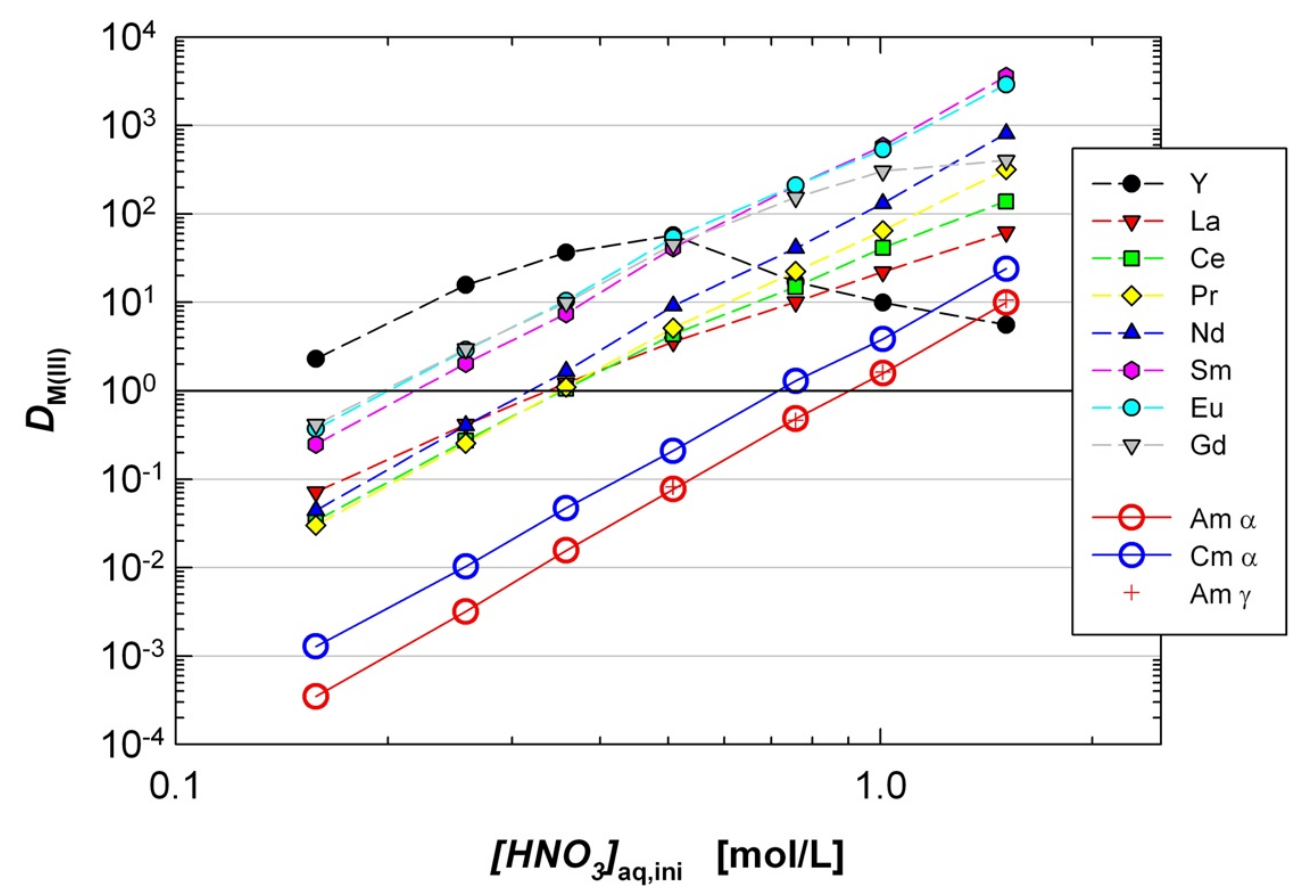

Figure 8. Distribution ratios of $\mathrm{Am}(\mathrm{III}), \mathrm{Cm}(\mathrm{III}), \mathrm{Y}(\mathrm{III})$, and light $\mathrm{Ln}(\mathrm{III})$ as a function of nitric acid concentration. Organic phase, $0.2 \mathrm{~mol} / \mathrm{L}$ TODGA $+5 \%$ vol. 1-octanol in Exxsol D80. Aqueous phase, ${ }^{241} \mathrm{Am}(\mathrm{III}),{ }^{244} \mathrm{Cm}(\mathrm{III})$, and ${ }^{152} \mathrm{Eu}(\mathrm{III})(1 \mathrm{kBq} / \mathrm{mL}$ each $)+\mathrm{Ln}(\mathrm{III})(6 \mathrm{mg} / \mathrm{L}$ each $)$ and $20 \mathrm{mmol} / \mathrm{L} \mathrm{SO}_{3}-\mathrm{Ph}-$ BTBP in $\mathrm{HNO}_{3}$. Data are from reference. ${ }^{122}$

The complexation of $\mathrm{Cm}$ (III) and $\mathrm{Eu}(\mathrm{III})$ with $\mathrm{SO}_{3}$-Ph-BTBP in various aqueous solutions $\left(10^{-3} \mathrm{~mol} / \mathrm{L}\right.$ and $0.5 \mathrm{~mol} / \mathrm{L} \mathrm{HClO}_{4}, 0.5 \mathrm{~mol} / \mathrm{L} \mathrm{HNO}_{3}, \mathrm{NaNO}_{3}$, and $\left.\mathrm{NaClO}_{4}\right)$ was studied using TRLFS. ${ }^{124} \mathrm{SO}_{3}$-Ph-BTBP was shown to form 1:2 complexes $\left[\mathrm{M}\left(\mathrm{SO}_{3}-\mathrm{Ph}-\mathrm{BTBP}\right)_{2}\right]^{5-}(\mathrm{M}=\mathrm{Cm}$, $\mathrm{Eu}$ ), as observed for hydrophobic BTBP. ${ }^{12,} 125$ The conditional stability constants show a systematic variation in dependence of acidity and ionic strength. The conditional stability constants in $10^{-3} \mathrm{~mol} / \mathrm{L} \mathrm{HClO}_{4}$ were determined to $\lg \beta_{2, \mathrm{Cm}(\mathrm{III})}=10.4 \pm 0.4$ and $\lg \beta_{2, \mathrm{Eu}(\mathrm{III})}=8.4$ \pm 0.4 . The difference, $\Delta \lg \beta_{02}=2$ was in good agreement with the respective difference observed for a lipophilic BTBP ${ }^{83}$ and with the $\mathrm{Cm}(\mathrm{III}) / \mathrm{Eu}(\mathrm{III})$ selectivity of $\mathrm{CyMe}_{4}-\mathrm{BTBP},{ }^{12}$ $S F_{\mathrm{Cm}(\mathrm{III}) / \mathrm{Eu}(\mathrm{III})} \approx 90$.

\section{$\mathrm{SO}_{3}-\mathrm{Ph}-\mathrm{BTPhen}$}

2,9-bis(5,6-di(3-sulphophenyl)-1,2,4-triazin-3-yl)-1,10-phenanthroline tetra-sodium salt ( $\mathrm{SO}_{3}$ Ph-BTPhen, Figure 7 bottom) was studied under similar conditions. ${ }^{126} \mathrm{~A}^{\mathrm{SO}_{3}-\mathrm{Ph}-}$ BTPhen/TODGA solvent extraction system performed slightly better than the respective system containing $\mathrm{SO}_{3}$-Ph-BTBP: $D_{\mathrm{Am}(\mathrm{III})}<1$ and $D_{\mathrm{Cm}(\mathrm{III}), \operatorname{Ln}(\mathrm{III})}>1$ for $\left[H N O_{3}\right] \approx 0.6 \mathrm{~mol} / \mathrm{L}$ 
with $S F_{\mathrm{Cm}(\mathrm{III}) / \mathrm{Am}(\mathrm{III})}=3.6$ (compared to $S F_{\mathrm{Cm}(\mathrm{III}) / \mathrm{Am}(\mathrm{III})} \approx 2.5^{122}$ ). With a stability constant of $\lg \beta_{2}$, $\mathrm{Cm}$ (III) $=10.7, \mathrm{SO}_{3}-\mathrm{Ph}-\mathrm{BTPhen}$ forms slightly more stable complexes with $\mathrm{Cm}$ (III) compared to $\mathrm{SO}_{3}$-Ph-BTBP $\left(\lg \beta_{2, \mathrm{Cm}(\mathrm{III})}=10.4^{124}\right)$. This trend, however more pronounced, was also observed for lipophilic BTBP and BTPhen. ${ }^{85}$

\section{Heteroleptic complexes}

The systems combining TODGA and hydrophilic ligands such as $\mathrm{SO}_{3}-\mathrm{Ph}-\mathrm{BTP}, \mathrm{SO}_{3}-\mathrm{Ph}-\mathrm{BTBP}$ or $\mathrm{SO}_{3}-\mathrm{Ph}-\mathrm{BTPhen}$ show an unexpected dependence of $\mathrm{Am}(\mathrm{III})$ and $\mathrm{Cm}$ (III) distribution ratios on ligand concentration: With $\mathrm{SO}_{3}-\mathrm{Ph}-\mathrm{BTP}$ forming 1:3 complexes ${ }^{116}$ and $\mathrm{SO}_{3}-\mathrm{Ph}-\mathrm{BTBP}$ and $\mathrm{SO}_{3}$-Ph-BTPhen forming 1:2 complexes, ${ }^{124,}{ }^{126}$ plots of $\lg D_{\text {Am(III) }}$ versus $\lg$ [ligand] should have slopes of $-3\left(\mathrm{SO}_{3}-\mathrm{Ph}-\mathrm{BTP}\right)$ or $-2\left(\mathrm{SO}_{3}-\mathrm{Ph}-\mathrm{BTBP}, \mathrm{SO}_{3}-\mathrm{Ph}-\mathrm{BTPhen}\right)$, respectively. However, slopes closer to $-2^{115,127}$ and $-1,{ }^{122,126}$ respectively, were found.

A study was carried out to verify whether this behaviour is caused by the formation of heteroleptic complexes in the organic phase, i.e. the replacement of a TODGA molecule by the hydrophilic ligand. ${ }^{128}$ Samples of both organic and aqueous phases from solvent extraction experiments with $\mathrm{Cm}(\mathrm{III})$ were studied by TRLFS. Only the respective complexes, $\left[\mathrm{Cm}\left(\mathrm{SO}_{3}-\right.\right.$ $\left.\mathrm{Ph}-\mathrm{BTP})_{3}\right]^{9-}$ and $\left[\mathrm{Cm}\left(\mathrm{SO}_{3}-\mathrm{Ph}-\mathrm{BTBP}\right)_{2}\right]^{5-}$ were detected in the aqueous phases. Organic phases only contained the TODGA complex, $\left[\mathrm{Cm}(\mathrm{TODGA})_{3}\right]^{3+}$, without any proof of a heteroleptic complex (see also reference ${ }^{124}$ ). However, $5.5 \times 10^{-5} \mathrm{~mol} / \mathrm{L} \mathrm{SO}_{3}-\mathrm{Ph}-\mathrm{BTP}$ was detected in the organic phase from a solvent extraction experiment involving elevated concentrations $(0.03 \mathrm{~mol} / \mathrm{L})$ of $\mathrm{Eu}(\mathrm{III}) .{ }^{128} \mathrm{Eu}(\mathrm{III})$ is not expected to partition to the organic phase as a homoleptic $\mathrm{SO}_{3}$-Ph-BTP complex. Hence, the finding that $\mathrm{SO}_{3}-\mathrm{Ph}-\mathrm{BTP}$ measurably partitions to the organic phase when higher concentrations of $\mathrm{Eu}(\mathrm{III})$ are extracted was seen as a clear indication for the formation of heteroleptic complexes. The heteroleptic complexes' concentration was estimated to $0.2 \%$ relative to the $\left[\operatorname{Eu}(\text { TODGA })_{3}\right]^{3+}$ complex, which was used as an explanation for why they could not be detected spectroscopically. Finally, the formation of such heteroleptic complexes was forced by preparing monophasic samples containing $\mathrm{Cm}$ (III), $\mathrm{SO}_{3}-\mathrm{Ph}-\mathrm{BTP}$ or $\mathrm{SO}_{3}-\mathrm{Ph}-\mathrm{BTBP}$, and TEDGA, a water soluble DGA. Indeed, emission spectra from heteroleptic complexes were identified (see Figure 9 for the TEDGA/SO $\mathrm{S}_{3}-\mathrm{Ph}-\mathrm{BTP}$ system). ${ }^{128}$ 


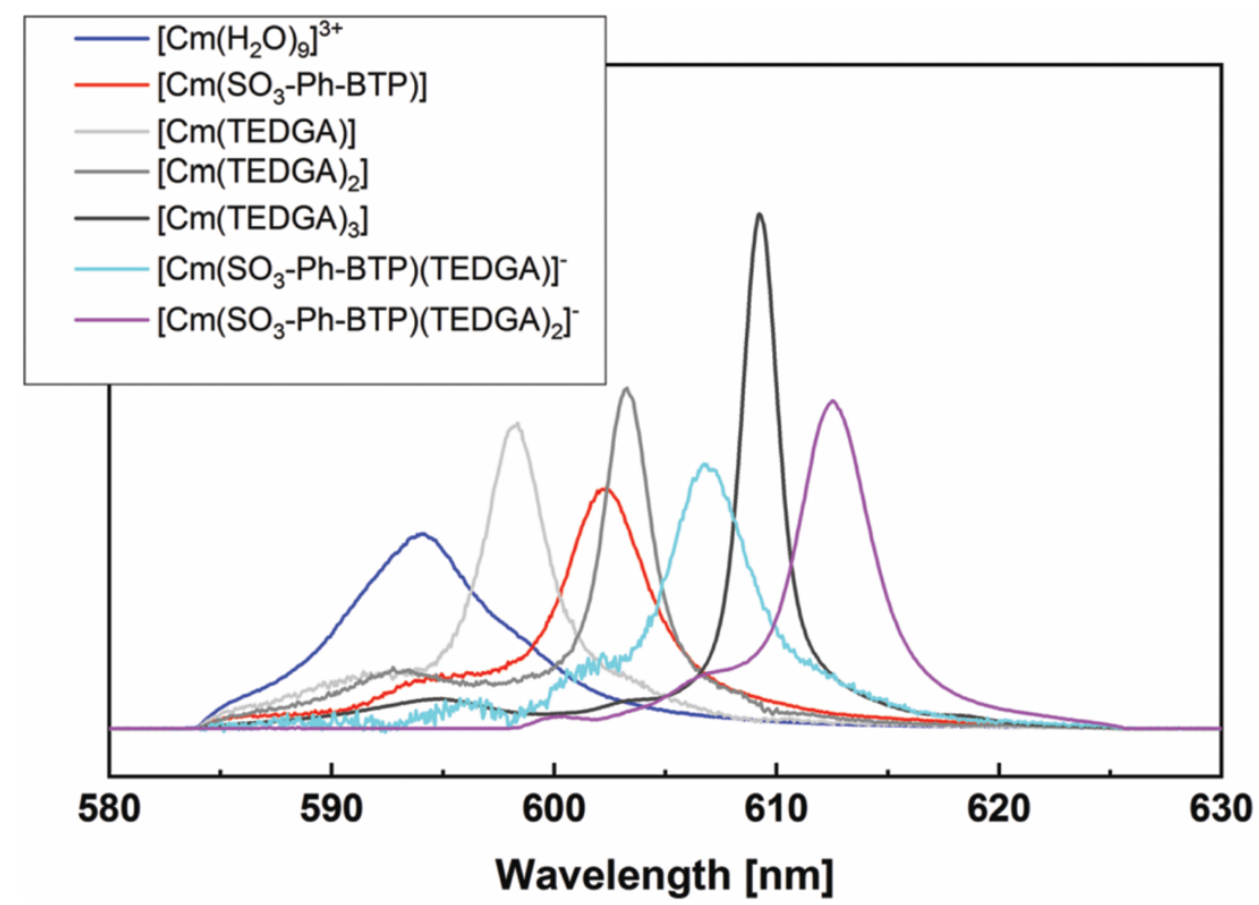

Figure 9. Pure component spectra of the $\mathrm{Cm}(\mathrm{III})$ complexes with $\mathrm{SO}_{3}-\mathrm{Ph}-\mathrm{BTP}$ and with TEDGA, and the heteroleptic complexes. Reproduced from reference ${ }^{128}$ by permission of The Royal Society of Chemistry (RSC) on behalf of the Centre National de la Recherche Scientifique (CNRS) and the RSC.

\section{Further hydrophilic ligands}

Since such stripping agents are not intended to be recycled, the sulphur content of $\mathrm{SO}_{3}-\mathrm{Ph}-\mathrm{BTP}$ and $\mathrm{SO}_{3}$ - $\mathrm{Ph}$-BTBP results in the generation of large volumes of solid secondary waste. This is a serious problem in a potential industrial application. Compounds containing only $\mathrm{C}, \mathrm{H}$, $\mathrm{O}$, or $\mathrm{N}$ atoms (known as $\mathrm{CHON}$ compounds) are combustible to gaseous products. ${ }^{129}$ Consequently, work focused on developing $C H O N$ compounds with properties similar to those of $\mathrm{SO}_{3}-\mathrm{Ph}$ BTP and $\mathrm{SO}_{3}$-Ph-BTBP. Unfortunately, compounds hydrophilised by carboxylate groups ${ }^{130}$ or quaternary ammonium functions ${ }^{58}$ turned out to be rather inefficient for the intended applications.

\section{PyTri-Diol}

A considerable breakthrough was achieved with the development of 2,6-bis(1,2,3-triazol-4yl)pyridine ligands hydrophilised with two, four, or six hydroxyl functions. ${ }^{75}$ These compounds allowed stripping Am(III) from a TODGA solvent containing Am(III) and Eu(III) with a selectivity up to $S F_{\mathrm{Eu}(\mathrm{III} / \mathrm{Am}(\mathrm{III})}=$ 240. 2,6-bis[1-(3-hydroxypropyl)-1,2,3-triazol-4-yl]pyridine (PyTri-Diol, Figure 10), containing two hydroxyl functions, was selected for further studies. 
<smiles>OCCCn1cc(-c2cccc(-c3cn(CCCO)nn3)n2)nn1</smiles>

Figure 10. Molecular structure of PyTri-Diol.

A study of the PyTri-Diol/TODGA system's applicability reports Am(III) and Ln(III) distribution data in dependence of PyTri-Diol (Figure 11) and nitric acid concentrations. ${ }^{131}$ Nitric acid and PyTri-Diol concentrations of $\approx 0.4 \mathrm{~mol} / \mathrm{L}$ and $0.08 \mathrm{~mol} / \mathrm{L}$, respectively, were identified as optimum conditions to selectively strip $\mathrm{An}(\mathrm{III})$, i. e. $D_{\text {An(III) }}<1$ and $D_{\text {Ln(III) }}>1$.

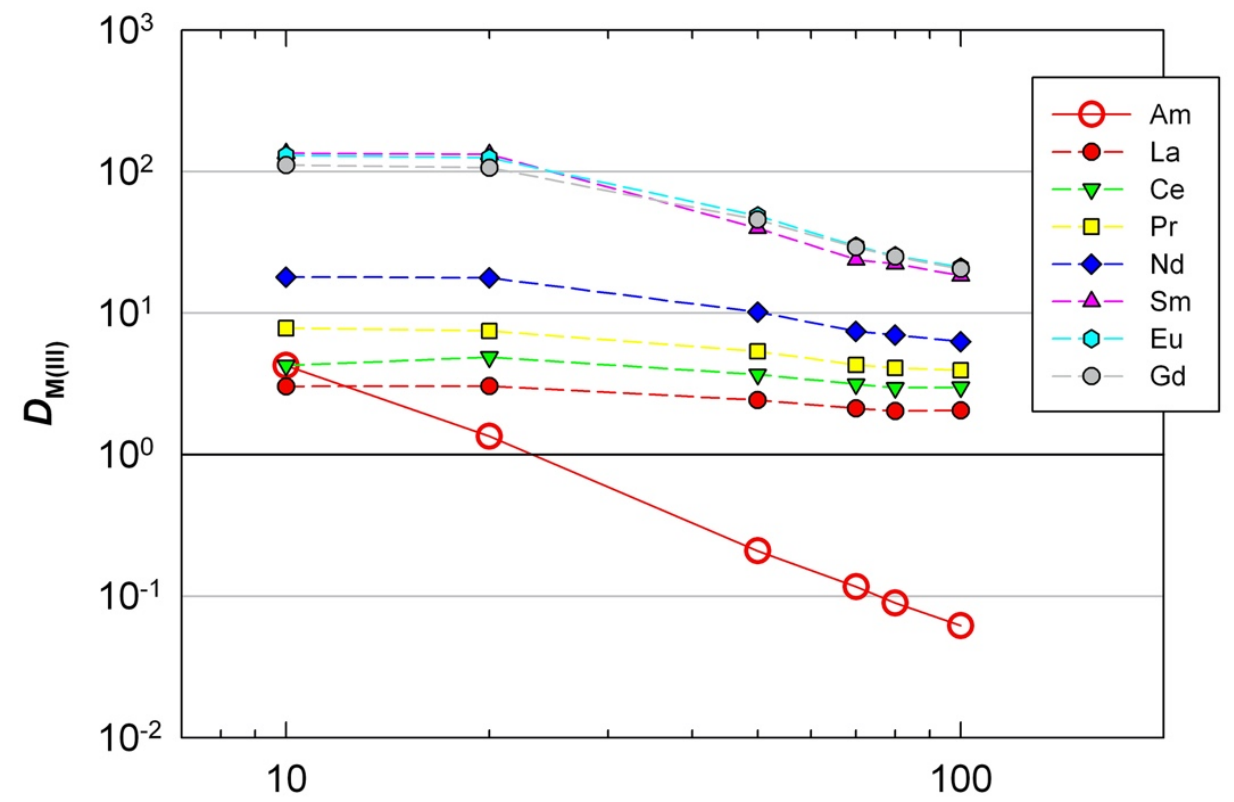

[PyTri-Diol] [mmol/L]

Figure 11. Am(III) and lighter $\mathrm{Ln}(\mathrm{III})$ distribution ratios as a function of PyTri-Diol concentration. Organic phase, $0.2 \mathrm{~mol} / \mathrm{L}$ TODGA +5 vol.\% 1-octanol in kerosene. Aqueous phase, PyTri-Diol, Am(III) and Ln(III) in $0.4 \mathrm{~mol} / \mathrm{L} \mathrm{HNO}_{3}$. Data are from reference. ${ }^{131}$

To better understand the behaviour of the PyTri-Diol/TODGA solvent extraction system, the complexation of $\mathrm{Cm}(\mathrm{III})$ and $\mathrm{Eu}(\mathrm{III})$ with PyTri-Diol was studied in different solutions $\left(10^{-3} \mathrm{~mol} / \mathrm{L} \mathrm{HClO}_{4}, 0.44 \mathrm{~mol} / \mathrm{L} \mathrm{HNO}_{3}\right.$; the latter to reflect conditions relevant to solvent extraction) and in aqueous phases from solvent extraction experiments using TRLFS. ${ }^{76}$ Conditional stability constants for the $1: 3 \mathrm{Cm}$ (III) complexes were $\log \beta_{3, \mathrm{Cm}(\mathrm{III})}=9.7 \pm 0.3$ $\left(10^{-3} \mathrm{~mol} / \mathrm{L} \mathrm{HClO}_{4}\right)$ and $\log \beta_{3, \mathrm{Cm}(\mathrm{III})}=5.7 \pm 0.3\left(0.44 \mathrm{~mol} / \mathrm{L} \mathrm{HNO}_{3}\right)$. This pronounced decrease was found to be due to ligand protonation $\left(\mathrm{p} K_{\mathrm{a}}=2.1^{75}\right)$. The respective $\mathrm{Eu}(\mathrm{III})$ stability constants were lower by approximately two orders of magnitude (similar differences between $\mathrm{Cm}(\mathrm{III})$ and $\mathrm{Eu}(\mathrm{III})$ stability constants were reported for BTP, ${ }^{82,} 84,116 \mathrm{BTBP},{ }^{83,} 124$ and BTPhen ${ }^{85}$ ). The aqueous phases from a $\mathrm{Cm}$ (III) solvent extraction experiment contained $22 \%$ 
1:2 complex and 78\% 1:3 complex. An equivalent experiment with $\mathrm{SO}_{3}-\mathrm{Ph}-\mathrm{BTP}$ revealed the formation of only the 1:3 complex. ${ }^{128}$ This difference explains the lower An(III)/Ln(III) selectivity of the PyTri-Diol/TODGA solvent extraction system ${ }^{75,131}$ compared to $\mathrm{SO}_{3}-\mathrm{Ph}$ BTP/TODGA. ${ }^{115}$

To increase the affinity of PyTri-Diol for An(III), an electron donating methoxy moiety was attached to the para position of the pyridine. ${ }^{132}$ This indeed resulted in an increased stability constant of the $\mathrm{Cm}$ (III) 1:3 complex from $\log \beta_{3, \mathrm{Cm}(\mathrm{III})}=9.9 \pm 0.5$ (PyTri-Diol) to $\log \beta_{3, \mathrm{Cm} \text { (III) }}$ $=10.8 \pm 0.4\left(\mathrm{PTD}-\mathrm{OMe}^{76}\right)$. Unfortunately, this came along with a greater $\mathrm{p} K_{\mathrm{a}}$ value $(2.54 \mathrm{vs}$. 2.1 for PyTri-Diol ${ }^{75}$ ), overcompensating the increased affinity for An(III) and resulting in inferior performance in solvent extraction experiments.

\section{A CHON BTPhen}

Based on the PyTri-Diol and PyTri-Tetraol compounds, the first $C H O N$ BTPhen ligands were synthesized and screened for $\mathrm{Am}(\mathrm{III}) / \mathrm{Eu}(\mathrm{III})$ and $\mathrm{Am}(\mathrm{III}) / \mathrm{Cm}(\mathrm{III})$ separation in combination with TODGA. ${ }^{133}$ Although Am(III)/Eu(III) selectivity was inferior to that of PyTriDiol, the new BTPhen/TODGA systems showed an appreciable selectivity for Cm(III) over Am(III), $S F_{\mathrm{Cm}(\mathrm{III}) / \mathrm{Am}(\mathrm{III})} \approx 2.5$. This value is comparable to that of the non-CHON $\mathrm{SO}_{3}-\mathrm{Ph}-\mathrm{BTBP} / \mathrm{TODGA}$ system. ${ }^{122}$ Unfortunately, the system had not been studied towards its selectivity between Am(III) and the lightest Ln(III), which is usually the bottleneck of such systems.

\section{Conclusions and outlook}

Our previous review ${ }^{7}$ on $\mathrm{BTP}$ and $\mathrm{BTBP}$ coordination and solvent extraction chemistry recapitulated the development and evolution of these ligands, from the first BTP up to water soluble $\mathrm{SO}_{3}-\mathrm{Ph}-\mathrm{BTP}$ and $\mathrm{SO}_{3}-\mathrm{Ph}-\mathrm{BTBP}$. We pointed out the link between fundamental complexation properties and solvent extraction behaviour. Compiling the structures, stoichiometry and stability of An(III) and Ln(III) complexes made evident a wealth of data on Ln(III) but a striking lack of data on An(III).

A traditional cook-and look approach to ligand development had largely been followed in early European research programmes. This resulted in a multitude of ligands, most of them without useful properties as extracting agents. More systematic approaches have been followed lately, focussing on the most promising backbones and considering insight from fundamental and theory studies.

For many years, finding experimental evidence for a larger covalent share in the An(III)-N bond compared to the Ln(III)-N bond was an important goal. The first few NMR studies on Am(III)BTP complexes finally provided such evidence. 
The Version of Record of this manuscript has been published and is available in SOLVENT EXTRACTION \& ION EXCHANGE 09 February 2021 https:/www.tandfonline.com/doi/full/10.1080/07366299.2020.1831235

Although application and process development were not covered in this review, the advent of hydrophilic BTBP and BTPhen ligands have promoted the development of processes for separating only $\mathrm{Am}(\mathrm{III})$ from $\mathrm{Cm}(\mathrm{III})$ and $\mathrm{Ln}(\mathrm{III})$. $\mathrm{CHON}$ alternatives to $\mathrm{SO}_{3}-\mathrm{Ph}$-BTBP has to be the next step.

The development of efficient processes for separating actinides should always be supported by fundamental studies. Such studies are not only of scientific value but also help closing gaps in process understanding.

\section{References}

1. Chiarizia, R.; Gatrone, R. C.; Horwitz, E. P., Am(III) and Eu(III) extraction by Aliquat-336 and benzyl substituted quaternary ammonium salts from nitrate and thiocyanate solutions. Solvent Extr. Ion Exch. 1995,13 (4), 615-645.

2. Chiarizia, R.; McAlister, D. R.; Herlinger, A. W., Trivalent actinide and lanthanide separations by dialkyl-substituted diphosphonic acids. Separ. Sci. Technol. 2005, 40 (1-3), 69-90.

3. Gannaz, B.; Chiarizia, R.; Antonio, M. R.; Hill, C.; Cote, G., Extraction of lanthanides(III) and Am(III) by mixtures of malonamide and dialkylphosphoric acid. Solvent Extr. Ion Exch. 2007, 25 (3), 313-337.

4. Jensen, M. P.; Chiarizia, R.; Shkrob, I. A.; Ulicki, J. S.; Spindler, B. D.; Murphy, D. J.; Hossain, M.; Roca-Sabio, A.; Platas-Iglesias, C.; de Blas, A.; Rodríguez-Blas, T., Aqueous complexes for efficient size-based separation of americium from curium. Inorg. Chem. 2014, 53 (12), 6003-6012.

5. Jensen, M. P.; Chiarizia, R.; Ulicki, J. S.; Spindler, B. D.; Murphy, D. J.; Hossain, M. M.; Roca-Sabio, A.; de Blas, A.; Rodríguez-Blas, T., Solvent extraction separation of trivalent americium from curium and the lanthanides. Solvent Extr. Ion Exch. 2015, 33 (4), 329-345.

6. Knight, A. W.; Chiarizia, R.; Soderholm, L., Extraction selectivity of a quaternary alkylammonium salt for trivalent actinides over trivalent lanthanides: does extractant aggregation play a role? Solvent Extr. Ion Exch. 2017, 35 (4), 266-279.

7. Panak, P. J.; Geist, A., Complexation and extraction of trivalent actinides and lanthanides by triazinylpyridine $N$-donor ligands. Chem. Rev. 2013, 113 (2), 1199-1236.

8. Modolo, G.; Geist, A.; Miguirditchian, M., Minor actinide separations in the reprocessing of spent nuclear fuels: recent advances in Europe. In Reprocessing and Recycling of Spent Nuclear Fuel, Taylor, R., Ed. Woodhead Publishing: Cambridge, UK, 2015.

9. Kolarik, Z.; Müllich, U.; Gassner, F., Selective extraction of Am(III) over Eu(III) by 2,6-ditriazolyland 2,6-ditriazinylpyridines. Solvent Extr. Ion Exch. 1999, 17 (1), 23-32.

10. Kolarik, Z.; Müllich, U.; Gassner, F., Extraction of Am(III) and Eu(III) nitrates by 2,6-di-(5,6-dipropyl1,2,4-triazin-3-yl)pyridines. Solvent Extr. Ion Exch. 1999, 17 (5), 1155-1170.

11. Foreman, M. R. S.; Hudson, M. J.; Drew, M. G. B.; Hill, C.; Madic, C., Complexes formed between the quadridentate, heterocyclic molecules 6,6 '-bis-(5,6-dialkyl-1,2,4-triazin-3-yl)-2,2 '-bipyridine (BTBP) and 
The Version of Record of this manuscript has been published and is available in SOLVENT EXTRACTION \& ION EXCHANGE 09 February 2021 https:/www.tandfonline.com/doi/full/10.1080/07366299.2020.1831235

lanthanides(III): implications for the partitioning of actinides(III) and lanthanides(III). Dalton Trans. 2006, (13), $1645-1653$.

12. Geist, A.; Hill, C.; Modolo, G.; Foreman, M. R. S. J.; Weigl, M.; Gompper, K.; Hudson, M. J.; Madic, C., 6,6 '-bis (5,5,8,8-tetramethyl-5,6,7,8-tetrahydro-benzo[1,2,4]triazin-3-yl) [2,2 ']bipyridine, an effective extracting agent for the separation of americium(III) and curium(III) from the lanthanides. Solvent Extr. Ion Exch. 2006, 24 (4), 463-483.

13. Ekberg, C.; Fermvik, A.; Retegan, T.; Skarnemark, G.; Foreman, M. R. S.; Hudson, M. J.; Englund, S.; Nilsson, M., An overview and historical look back at the solvent extraction using nitrogen donor ligands to extract and separate An(III) from Ln(III). Radiochim. Acta 2008, 96 (4-5), 225-233.

14. Lewis, F. W.; Hudson, M. J.; Harwood, L. M., Development of highly selective ligands for separations of actinides from lanthanides in the nuclear fuel cycle. Synlett 2011, 18, 2609-2632.

15. Hudson, M. J.; Harwood, L. M.; Laventine, D. M.; Lewis, F. W., Use of soft heterocyclic $N$-donor ligands to separate actinides and lanthanides. Inorg. Chem. 2013, 52 (7), 3414-3428.

16. Hudson, M. J.; Lewis, F. W.; Harwood, L. M., The circuitous journey from malonamides to BTPhens: ligands for separating actinides from lanthanides. In Strategies and Tactics in Organic Synthesis, Michael, H., Ed. Academic Press: 2013; Vol. Volume 9, pp 177-202.

17. Gorden, A. E. V.; DeVore, M. A.; Maynard, B. A., Coordination chemistry with $f$-element complexes for an improved understanding of factors that contribute to extraction selectivity. Inorg. Chem. 2013, 52 (7), 3445-3458.

18. Dan, D.; Celis-Barros, C.; White, F. D.; Sperling, J. M.; Albrecht-Schmitt, T. E., Origin of selectivity of a triazinyl ligand for americium(III) over neodymium(III). Chem. Eur. J. 2019, 25 (13), 3248-3252.

19. Aneheim, E.; Ekberg, C.; Foreman, M. R. S., A TBP/BTBP-based GANEX separation process — part 3: fission product handling. Solvent Extr. Ion Exch. 2013, 31 (3), 237-252.

20. Löfström-Engdahl, E.; Aneheim, E.; Ekberg, C.; Foreman, M.; Skarnemark, G., Comparison of the extraction as a function of time in two GANEX solvents: influence of metal loading, interfacial tension, and density. Solvent Extr. Ion Exch. 2013, 31 (6), 604-616.

21. Magnusson, D.; Geist, A.; Malmbeck, R.; Müllich, U., Study of the mass transfer behavior in a centrifugal contactor and verification of the solvent extraction model for the SX Process program. Solvent Extr. Ion Exch. 2013, 31 (6), 578-589.

22. Modolo, G.; Wilden, A.; Daniels, H.; Geist, A.; Magnusson, D.; Malmbeck, R., Development and demonstration of a new SANEX partitioning process for selective actinide(III)/lanthanide(III) separation using a mixture of CyMe-BTBP and TODGA. Radiochim. Acta 2013, 101 (3), 155-162.

23. Wilden, A.; Modolo, G.; Schreinemachers, C.; Sadowski, F.; Lange, S.; Sypula, M.; Magnusson, D.; Geist, A.; Lewis, F. W.; Harwood, L. M.; Hudson, M. J., Direct selective extraction of actinides (III) from PUREX raffinate using a mixture of $\mathrm{CyMe}_{4}-\mathrm{BTBP}$ and TODGA as 1-cycle SANEX solvent part III: Demonstration of a laboratory-scale counter-current centrifugal contactor process. Solvent Extr. Ion Exch. 2013, 31 (5), 519-537. 
The Version of Record of this manuscript has been published and is available in SOLVENT EXTRACTION \& ION EXCHANGE 09 February 2021 https:/www.tandfonline.com/doi/full/10.1080/07366299.2020.1831235

24. Aneheim, E.; Ekberg, C.; Modolo, G.; Wilden, A., Single centrifugal contactor test of a proposed group actinide extraction process for partitioning and transmutation purposes. Separ. Sci. Technol. 2014, 50 (10), $1554-1559$.

25. Carrott, M.; Geist, A.; Hérès, X.; Lange, S.; Malmbeck, R.; Miguirditchian, M.; Modolo, G.; Wilden, A.; Taylor, R., Distribution of plutonium, americium and interfering fission products between nitric acid and a mixed organic phase of TODGA and DMDOHEMA in kerosene, and implications for the design of the "EUROGANEX” process. Hydrometallurgy 2015, 152, 139-148.

26. Wilden, A.; Modolo, G.; Kaufholz, P.; Sadowski, F.; Lange, S.; Sypula, M.; Magnusson, D.; Müllich, U.; Geist, A.; Bosbach, D., Laboratory-scale counter-current centrifugal contactor demonstration of an innovative-SANEX process using a water soluble BTP. Solvent Extr. Ion Exch. 2015, 33 (2), 91-108.

27. Carrott, M.; Maher, C.; Mason, C.; Sarsfield, M.; Taylor, R., "TRU-SANEX”: A variation on the EURO-GANEX and i-SANEX processes for heterogeneous recycling of actinides Np-Cm. Separ. Sci. Technol. 2016, 51 (13), 2198-2213.

28. Halleröd, J.; Ekberg, C.; Authen, T.; Bertolo, L.; Lin, M.; Grüner, B.; Švehla, J.; Wagner, C.; Geist, A.; Panak, P. J.; Aneheim, E., On the basic extraction properties of a phenyl trifluoromethyl sulfone-based GANEX system containing CyMe-BTBP and TBP. Solvent Extr. Ion Exch. 2018, 36 (4), 360-372.

29. Bhattacharyya, A.; Ansari, S. A.; Prabhu, D. R.; Kumar, D.; Mohapatra, P. K., Highly efficient separation of $\mathrm{Am}^{3+}$ and $\mathrm{Eu}^{3+}$ using an aqueous soluble sulfonated BTP derivative by hollow-fiber supported liquid membrane containing TODGA. Separ. Sci. Technol. 2019, 54 (9), 1512-1520.

30. Malmbeck, R.; Magnusson, D.; Bourg, S.; Carrott, M.; Geist, A.; Hérès, X.; Miguirditchian, M.; Modolo, G.; Müllich, U.; Sorel, C.; Taylor, R.; Wilden, A., Homogenous recycling of transuranium elements from irradiated fast reactor fuel by the EURO-GANEX solvent extraction process. Radiochim. Acta 2019, 107 (9-11), 917-929.

31. Matsumura, T.; Matsumura, K.; Morita, Y.; Koma, Y.; Sano, Y.; Nomura, K., Separation of trivalent minor actinides from fission products using single R-BTP column extraction chromatography. J. Nucl. Sci. Technol. 2011, 48 (6), 855-858.

32. Deepika, P.; Sabharwal, K. N.; Srinivasan, T. G.; Rao, P. R. V., Studies on bis annulated triazinyl pyridine (BATP) using extraction chromatography. Separ. Sci. Technol. 2013, 48 (13), 2020-2027.

33. Klug, C.; Sudowe, R., A novel extraction chromatography resin for trivalent actinides using 2,6-bis(5,6diisobutyl-1,2,4-triazine-3-yl)pyridine. Separ. Sci. Technol. 2013, 48 (17), 2567-2575.

34. Afsar, A.; Harwood, L. M.; Hudson, M. J.; Distler, P.; John, J., Effective separation of Am(III) and $\mathrm{Eu}(\mathrm{III})$ from $\mathrm{HNO}_{3}$ solutions using $\mathrm{CyMe}_{4}-\mathrm{BTPhen}$-functionalized silica-coated magnetic nanoparticles. Chem. Commun. 2014, 50 (95), 15082-15085.

35. Liu, R.; Wang, X.; Wei, Y.; Shi, W.; Chai, Z., Evaluation study on a macroporous silica-based isohexyl-BTP adsorbent for minor actinides separation from nitric acid medium. Radiochim. Acta 2014, 102 (12), 93-100. 
The Version of Record of this manuscript has been published and is available in SOLVENT EXTRACTION \& ION EXCHANGE 09 February 2021 https:/www.tandfonline.com/doi/full/10.1080/07366299.2020.1831235

36. Veliscek-Carolan, J.; Jolliffe, K. A.; Hanley, T. L., Effective Am(III)/Eu(III) separations using 2,6bis(1,2,4-triazin-3-yl)pyridine (BTP) functionalised titania particles and hierarchically porous beads. Chem. Commun. 2015, 51 (57), 11433-11436.

37. Wang, X.; Ning, S.; Zou, Q.; Liu, R.; Wei, Y., Adsorption behavior and mechanism of isobutylBTP/SiO2-P adsorbent for Am(III) and Ln(III) in nitrate solution. J. Radioanal. Nucl. Chem. 2016, 307 (3), 2001-2008.

38. Tevepaugh, K. N.; Coonce, J.; Tai, S.; Delmau, L. H.; Carrick, J. D.; Ensor, D. D., Chromatographic separation of americium from europium using bis-2,6-(5,6,7,8-tetrahydro-5,9,9-trimethyl-5,8-methano-1,2,4benzotriazin-3-yl) pyridine. J. Radioanal. Nucl. Chem. 2017, 314 (1), 371-376.

39. Afsar, A.; Westwood, J.; Distler, P.; Harwood, L. M.; Mohan, S.; John, J.; Davis, F. J., Separation of $\mathrm{Am}(\mathrm{III}), \mathrm{Cm}(\mathrm{III})$ and $\mathrm{Eu}(\mathrm{III})$ by electro-spun polystyrene-immobilized CyMe $4-B T P h e n$. Tetrahedron 2018, 74 (38), 5258-5262.

40. Ning, S. Y.; Zhang, W.; Yu, S. Q.; Zhang, S. C.; Zhou, J.; Wang, X. P.; Wei, Y. Z., Selective separation of MA(III) from Ln(III) by highly stable silica-polymer-based $N$-donor IsoBu-BTP/SiO $2-\mathrm{P}$ adsorbent. Solvent Extr. Ion Exch. 2019, 37 (2), 126-139.

41. Galán, H.; Munzel, D.; Núñez, A.; Müllich, U.; Cobos, J.; Geist, A., Stability and recyclability of $\mathrm{SO}_{3}-$ Ph-BTP for i-SANEX process development. In Proc. Internat. Solvent Extr. Conf. (ISEC 2014), Würzburg, Germany, 7-11 September, 2014; pp 137-143.

42. Sulich, A.; Grodkowski, J.; Mirkowski, J.; Kocia, R., Reactions of ligands from BT(B)P family with solvated electrons and benzophenone ketyl radicals in 1-octanol solutions. Pulse radiolysis study. J. Radioanal. Nucl. Chem. 2014, 300 (1), 415-421.

43. Zhou, H.; Ao, Y.; Yuan, J.; Peng, J.; Li, J.; Zhai, M., Extraction mechanism and $\gamma$-radiation effect on the removal of $\mathrm{Eu}^{3+}$ by a novel BTPhen $/\left[\mathrm{C}_{n} \operatorname{mim}\right]\left[\mathrm{NTf}_{2}\right]$ system in the presence of nitric acid. RSC Advances 2014, 4 (85), 45612-45618.

44. Halleröd, J.; Ekberg, C.; Foreman, M.; Löfström-Engdahl, E.; Aneheim, E., Stability of phenyl trifluoromethyl sulfone as diluent in a grouped actinide extraction process. J. Radioanal. Nucl. Chem. 2015, 304 (1), 287-291.

45. Peterman, D.; Geist, A.; Mincher, B.; Modolo, G.; Galán, M. H.; Olson, L.; McDowell, R., Performance of an i-SANEX system based on a water soluble BTP under continuous irradiation in a $\gamma$-radiolysis test loop. Ind. Eng. Chem. Res. 2016, 55 (39), 10427-10435.

46. Schmidt, H.; Wilden, A.; Modolo, G.; Bosbach, D.; Santiago-Schübel, B.; Hupert, M.; Švehla, J.; Grüner, B.; Ekberg, C., Gamma radiolysis of the highly selective ligands CyMe4-BTBP and CyMe4-BTPhen: qualitative and quantitative investigation of radiolysis products. Proc. Chem. 2016, 21, 32-37.

47. Ao, Y.; Yuan, W.; Pan, Q.; Wang, Y.; Chen, J.; Zhao, L.; Li, J.; Zhai, M., Radiolysis of alkyl substituted tridentate 2,6-bis(1,2,4-triazine-3-yl)pyridines: an experimental study with DFT validation. New J. Chem. 2018, 42 (22), 18395-18401. 
The Version of Record of this manuscript has been published and is available in SOLVENT EXTRACTION \& ION EXCHANGE 09 February 2021 https://www.tandfonline.com/doi/full/10.1080/07366299.2020.1831235

48. Horne, G. P.; Mezyk, S. P.; Moulton, N.; Peller, J. R.; Geist, A., Time-resolved and steady-state irradiation of hydrophilic sulfonated bis-triazinyl-(bi)pyridines - modelling radiolytic degradation. Dalton Trans. 2019, 48 (14), 4547-4554.

49. Szreder, T.; Schmidt, H.; Modolo, G., Fast radiation-induced reactions in organic phase of SANEX system containing CyMe-BTPhen extracting agent. Radiat. Phys. Chem. 2019, 164, 108356.

50. Zsabka, P.; Van Hecke, K.; Wilden, A.; Modolo, G.; Hupert, M.; Jespers, V.; Voorspoels, S.; Verwerft, M.; Binnemans, K.; Cardinaels, T., Gamma radiolysis of TODGA and CyMe $4-B T P h e n$ in the ionic liquid tri-noctylmethylammonium nitrate. Solvent Extr. Ion Exch. 2020, 38 (2), 212-235.

51. Aneheim, E.; Grüner, B.; Ekberg, C.; Foreman, M. R. S.; Hájková, Z.; Löfström-Engdahl, E.; Drew, M. G. B.; Hudson, M. J., Fission product interactions with nitrogen donor ligands used for spent nuclear fuel treatment. Polyhedron 2013, 50 (1), 154-163.

52. Yang, X.; Liang, Y.; Ding, S.; Li, S.; Chai, Z.; Wang, D., Influence of a bridging group and the substitution effect of bis(1,2,4-triazine) $N$-donor extractants on their interactions with a $\mathrm{Np}(\mathrm{V})$ cation. Inorg. Chem. 2014, 53 (15), 7848-7860.

53. Lewis, F. W.; Harwood, L. M.; Hudson, M. J.; Müllich, U.; Geist, A., Efficient masking of corrosion and fission products such as $\mathrm{Ni}(\mathrm{II})$ and $\mathrm{Pd}(\mathrm{II})$ in the presence of the minor actinide Am(III) using hydrophilic anionic or cationic bis-triazines. Chem. Commun. 2015, 51 (44), 9189-9192.

54. Xu, L.; Zhang, A.; Pu, N.; Lu, Y.; Yang, H.; Liu, Z.; Ji, Y., Unusual complexation behaviors of R-BTPs with water molecule and $\mathrm{Pd}(\mathrm{II})$ caused by electronic modulation of substituents on BTP backbone: new insights into palladium separation under the framework of minor actinides' partitioning. New J. Chem. 2019, 43 (23), 9052-9065.

55. Steczek, Ł.; Narbutt, J.; Charbonnel, M.-C.; Moisy, P., Solvent extraction investigations on Pu(IV) and $\mathrm{Th}(\mathrm{IV})$ complexes with hydrophilic $\mathrm{SO}_{3}-\mathrm{Ph}-\mathrm{BTP}$ and $\mathrm{SO}_{3}-\mathrm{Ph}-\mathrm{BTBP}$ ligands. Solvent Extr. Ion Exch. 2019, 37 (3-4), 259-268.

56. Ayabe, T.; Costes, J.-P.; Vendier, L.; Geist, A.; Takeda, M.; Takahashi, M., Contribution of 155Gd Mössbauer data to the study of the magnetic interaction in heterodinuclear $3 \mathrm{~d}-\mathrm{Gd}(3 \mathrm{~d}=\mathrm{Cu}, \mathrm{Ni})$ coordination complexes. Dalton Trans. 2019, 48 (20), 6872-6878.

57. Lan, J.-H.; Shi, W.-Q.; Yuan, L.-Y.; Li, J.; Zhao, Y.-L.; Chai, Z.-F., Recent advances in computational modeling and simulations on the An(III)/Ln(III) separation process. Coord. Chem. Rev. 2012, 256 (13-14), 1406-1417.

58. Benay, G.; Wipff, G., Oil-soluble and water-soluble BTPhens and their europium complexes in octanol/water solutions: interface crossing studied by MD and PMF simulations. J. Phys. Chem. B 2013, 117 (4), $1110-1122$.

59. Liang, Y.-N.; Yang, X.; Ding, S.; Li, S.; Wang, F.; Chai, Z.; Wang, D., Computational thermodynamic study on the complexes of Am(III) with tridentate $N$-donor ligands. New J. Chem. 2015, 39 (10), 7716-7729.

60. Narbutt, J.; Wodynski, A.; Pecul, M., The selectivity of diglycolamide (TODGA) and bis-triazinebipyridine (BTBP) ligands in actinide/lanthanide complexation and solvent extraction separation - a theoretical approach. Dalton Trans. 2015, 44, 2657-2666. 
The Version of Record of this manuscript has been published and is available in SOLVENT EXTRACTION \& ION EXCHANGE 09 February 2021 https:/www.tandfonline.com/doi/full/10.1080/07366299.2020.1831235

61. Fryer-Kanssen, I.; Austin, J.; Kerridge, A., Topological study of bonding in aquo and bis(triazinyl)pyridine complexes of trivalent lanthanides and actinides: does covalency imply stability? Inorg. Chem. 2016, 55 (20), 10034-10042.

62. Trumm, M.; Schimmelpfennig, B., Towards the origin of effective An(III)/Ln(III) separation by tridentate $N$-donor ligands: a theoretical study on atomic charges and polarisabilities for $\mathrm{Cm}(\mathrm{III}) / \mathrm{Gd}(\mathrm{III})$ separation. Molecular Physics 2016, 114 (6), 876-883.

63. Wu, H.; Wu, Q.-Y.; Wang, C.-Z.; Lan, J.-H.; Liu, Z.-R.; Chai, Z.-F.; Shi, W.-Q., New insights into the selectivity of four 1,10-phenanthroline-derived ligands toward the separation of trivalent actinides and lanthanides: a DFT based comparison study. Dalton Trans. 2016, 45 (19), 8107-8117.

64. Lan, J.-H.; Wu, Q.-Y.; Wang, C.-Z.; Chai, Z.-F.; Shi, W.-Q., Influence of complexing species on the extraction of trivalent actinides from lanthanides with CyMe 4 -BTBP: a theoretical study. J. Radioanal. Nucl. Chem. 2018, 318 (3), 1453-1463.

65. Trumm, M.; Wagner, C.; Schimmelpfennig, B.; Geist, A.; Panak, P. J., A closer look on the coordination of soft nitrogen-donor ligands to Cm(III): SO3-Ph-BTBP. Dalton Trans. 2016, 45 (31), 1230812311.

66. Trumm, M.; Schimmelpfennig, B.; Geist, A., Structure and separation quality of various N- and Odonor ligands from quantum-chemical calculations. Nukleonika 2015, 60 (4), 847-851.

67. Hill, T. G.; Chin, A. L.; Tai, S.; Carrick, J. D.; Ensor, D. D.; Delmau, L. H., Separation of americium from europium using 3,3'-dimethoxy-phenyl-bis-1,2,4-triazinyl-2,6-pyridine. Separ. Sci. Technol. 2017, 1-8.

68. Dupont, C.; Hill, C.; Suzenet, F.; Guillaumet, G., Influence of an alkoxy group on bis-triazinylpyridines for selective extraction of americium(III). Solvent Extr. Ion Exch. 2013, 31 (3), 253-268.

69. Retegan, T.; Drew, M. G. B.; Ekberg, C.; Löfström Engdahl, E.; Hudson, M. J.; Fermvik, A.; Foreman, M. R. S.; Modolo, G.; Geist, A., Synthesis and screening of $t$-Bu-CyMe4-BTBP, and comparison with CyMe4BTBP. Solvent Extr. Ion Exch. 2014, 32 (7), 720-736.

70. Trumm, S.; Geist, A.; Panak, P. J.; Fanghänel, T., An improved hydrolytically-stable bis-triazinylpyridine (BTP) for selective actinide extraction. Solvent Extr. Ion Exch. 2011, 29 (2), 213-229.

71. Tevepaugh, K. N.; Carrick, J. D.; Tai, S.; Coonce, J. G.; Delmau, L. H.; Ensor, D. D., Separation of americium from europium using camphor-bistriazinyl pyridine: a fundamental study. Solvent Extr. Ion Exch. 2016, 34 (1), 13-25.

72. $\quad$ Bremer, A.; Ruff, C. M.; Girnt, D.; Müllich, U.; Rothe, J.; Roesky, P. W.; Panak, P. J.; Karpov, A.; Müller, T. J. J.; Denecke, M. A.; Geist, A., 2,6-Bis(5-(2,2-dimethylpropyl)-1H-pyrazol-3-yl)pyridine as a ligand for efficient actinide(III)/lanthanide(III) separation. Inorg. Chem. 2012, 51 (9), 5199-5207.

73. Beele, B. B.; Müllich, U.; Schwörer, F.; Geist, A.; Panak, P. J., Systematic modifications of BTP-type ligands and effects on the separation of trivalent lanthanides and actinides. Proc. Chem. 2012, 7, 146-151.

74. Kolarik, Z., Complexation and separation of lanthanides(III) and actinides(III) by heterocyclic $N$-donors in solutions. Chem. Rev. 2008, 108 (10), 4208-4252. 
The Version of Record of this manuscript has been published and is available in SOLVENT EXTRACTION \& ION EXCHANGE 09 February 2021 https://www.tandfonline.com/doi/full/10.1080/07366299.2020.1831235

75. Macerata, E.; Mossini, E.; Scaravaggi, S.; Mariani, M.; Mele, A.; Panzeri, W.; Boubals, N.; Berthon, L.; Charbonnel, M.-C.; Sansone, F.; Arduini, A.; Casnati, A., Hydrophilic clicked 2,6-bis-triazolyl-pyridines endowed with high actinide selectivity and radiochemical stability: toward a closed nuclear fuel cycle. J. Amer. Chem. Soc. 2016, 138 (23), 7232-7235.

76. Wagner, C.; Mossini, E.; Macerata, E.; Mariani, M.; Arduini, A.; Casnati, A.; Geist, A.; Panak, P. J., Time-resolved laser fluorescence spectroscopy study of the coordination chemistry of a hydrophilic CHON [1,2,3-triazol-4-yl]pyridine ligand with Cm(III) and Eu(III). Inorg. Chem. 2017, 56 (4), 2135-2144.

77. Ossola, A.; Macerata, E.; Mossini, E.; Giola, M.; Gullo, M. C.; Arduini, A.; Casnati, A.; Mariani, M., 2,6-Bis(1-alkyl-1H-1,2,3-triazol-4-yl)-pyridines: selective lipophilic chelating ligands for minor actinides. $J$. Radioanal. Nucl. Chem. 2018, 318 (3), 2013-2022.

78. de Sahb, C.; Watson, L. A.; Nadas, J.; Hay, B. P., Design criteria for polyazine extractants to separate An(III) from Ln(III). Inorg. Chem. 2013, 52 (18), 10632-10642.

79. Beele, B. B.; Rüdiger, E.; Schwörer, F.; Müllich, U.; Geist, A.; Panak, P. J., A TRLFS study on the complexation of novel BTP type ligands with Cm(III). Dalton Trans. 2013, 42 (34), 12139-12147.

80. Bhattacharyya, A.; Kim, E.; Weck, P. F.; Forster, P. M.; Czerwinski, K. R., Trivalent actinide and lanthanide complexation of 5,6-dialkyl-2,6-bis(1,2,4-triazin-3-yl)pyridine (RBTP; $\mathrm{R}=\mathrm{H}, \mathrm{Me}, \mathrm{Et})$ derivatives: a combined experimental and first-principles study. Inorg. Chem. 2013, 52 (2), 761-776.

81. Bhattacharyya, A.; Mohapatra, M.; Mohapatra, P. K.; Gadly, T.; Ghosh, S. K.; Manna, D.; Ghanty, T. K.; Rawat, N.; Tomar, B. S., An insight into the complexation of trivalent americium vis-à-vis lanthanides with bis(1,2,4-triazinyl)bipyridine derivatives. Eur. J. Inorg. Chem. 2017, (4), 820-828.

82. Trumm, S.; Panak, P. J.; Geist, A.; Fanghänel, T., A TRLFS study on the complexation of Cm(III) and Eu(III) with 2,6-bis(5,6-dipropyl-1,2,4-triazin-3-yl)pyridine in water/methanol mixture. Eur. J. Inorg. Chem. 2010, (19), 3022-3028.

83. Trumm, S.; Lieser, G.; Foreman, M. R. S.; Panak, P. J.; Geist, A.; Fanghänel, T., A TRLFS study on the complexation of $\mathrm{Cm}$ (III) and Eu(III) with 4-t-butyl-6,6 '-bis-(5,6-diethyl-1,2,4-triazin-3-yl)-2,2 '-bipyridine in a water/2-propanol mixture. Dalton Trans. 2010, 39 (3), 923-929.

84. Bremer, A.; Müllich, U.; Geist, A.; Panak, P. J., Influence of the solvent on the complexation of Cm(III) and $\mathrm{Eu}(\mathrm{III})$ with nPr-BTP studied by time-resolved laser fluorescence spectroscopy. New J. Chem. 2015, 39 (2), $1330-1338$.

85. Bremer, A.; Whittaker, D. M.; Sharrad, C. A.; Geist, A.; Panak, P. J., Complexation of Cm(III) and Eu(III) with $\mathrm{CyMe}_{4}$-BTPhen and $\mathrm{CyMe}_{4}$-BTBP studied by time resolved laser fluorescence spectroscopy. Dalton Trans. 2014, 43 (6), 2684-2694.

86. Trumm, S.; Lieser, G.; Panak, P. J., Luminescence study on the solvation of Cm(III) in binary aqueous solvent mixtures. Radiochim. Acta 2011, 99 (12), 783-790.

87. Hudson, M. J.; Boucher, C. E.; Braekers, D.; Desreux, J. F.; Drew, M. G. B.; Foreman, M. R. S.; Harwood, L. M.; Hill, C.; Madic, C.; Marken, F.; Youngs, T. G. A., New bis(triazinyl) pyridines for selective extraction of americium(III). New J. Chem. 2006, 30 (8), 1171-1183. 
The Version of Record of this manuscript has been published and is available in SOLVENT EXTRACTION \& ION EXCHANGE 09 February 2021 https://www.tandfonline.com/doi/full/10.1080/07366299.2020.1831235

88. Iveson, P. B.; Riviere, C.; Guillaneux, D.; Nierlich, M.; Thuery, P.; Ephritikhine, M.; Madic, C., Selective complexation of uranium(III) over cerium(III) by 2,6-bis(5,6-dialkyl-1,2,4-triazin-3-yl)pyridines: H-1 NMR and X-ray crystallography studies. Chem. Commun. 2001, (16), 1512-1513.

89. Lewis, F. W.; Harwood, L. M.; Hudson, M. J.; Distler, P.; John, J.; Stamberg, K.; Núñez, A.; Galán, H.; Espartero, A. G., Synthesis and evaluation of lipophilic BTBP ligands for An/Ln separation in nuclear waste treatment: the effect of alkyl substitution on extraction properties and implications for ligand design. Eur. J. Org. Chem. 2012, (8), 1509-1519.

90. Laventine, D. M.; Afsar, A.; Hudson, M. J.; Harwood, L. M., Tuning the solubilities of bistriazinylphenanthroline ligands (BTPhens) and their complexes. Heterocycles 2012, 86 (2), 1419-1429.

91. Lewis, F. W.; Harwood, L. M.; Hudson, M. J.; Drew, M. G. B.; Wilden, A.; Sypula, M.; Modolo, G.; Vu, T.-H.; Simonin, J.-P.; Vidick, G.; Bouslimani, N.; Desreux, J. F., From BTBPs to BTPhens: the effect of ligand pre-organization on the extraction properties of quadridentate bistTriazine ligands. Proc. Chem. 2012, 7 , $231-238$

92. Afsar, A.; Laventine, D. M.; Harwood, L. M.; Hudson, M. J.; Geist, A., Utilizing electronic effects in the modulation of BTPhen ligands with respect to the partitioning of minor actinides from lanthanides. Chem. Commun. 2013, 49 (76), 8534-8536.

93. Lewis, F. W.; Harwood, L. M.; Hudson, M. J.; Drew, M. G. B.; Hubscher-Bruder, V.; Videva, V.; Arnaud-Neu, F.; Stamberg, K.; Vyas, S., BTBPs versus BTPhens: some reasons for their differences in properties concerning the partitioning of minor actinides and the advantages of BTPhens. Inorg. Chem. 2013, 52 (9), 4993-5005

94. Afsar, A.; Westwood, J.; Harwood, L. M.; Hudson, M. J.; Laventine, D. M.; Geist, A., The effect of alkyl substitution on the extraction properties of BTPhen ligands for the partitioning of trivalent minor actinides and lanthanides in spent nuclear fuels. Jordan J. Chem. 2014, 9 (1), 50-58.

95. Zaytsev, A. V.; Bulmer, R.; Kozhevnikov, V. N.; Sims, M.; Modolo, G.; Wilden, A.; Waddell, P. G.; Geist, A.; Panak, P. J.; Weßling, P.; Lewis, F. W., Exploring the subtle effect of aliphatic ring size on minor actinide-extraction properties and metal ion speciation in bis-1,2,4-triazine ligands. Chem. Eur. J. 2020, 26 (2), $428-437$.

96. Adam, C.; Kaden, P.; Beele, B. B.; Müllich, U.; Trumm, S.; Geist, A.; Panak, P. J.; Denecke, M. A., Evidence for covalence in a $N$-donor complex of americium(III). Dalton Trans. 2013, 42 (39), 14068-14074.

97. Adam, C.; Rohde, V.; Müllich, U.; Kaden, P.; Geist, A.; Panak, P. J.; Geckeis, H., Comparative NMR study of $n$ PrBTP and $i$ PrBTP. Proc. Chem. 2016, 21, 38-45.

98. Adam, C.; Beele, B. B.; Geist, A.; Müllich, U.; Kaden, P.; Panak, P. J., NMR and TRLFS studies of Ln(III) and An(III) C5-BPP complexes. Chem. Sci. 2015, 6 (2), 1548-1561.

99. Lewis, F. W.; Harwood, L. M.; Hudson, M. J.; Drew, M. G. B.; Desreux, J. F.; Vidick, G.; Bouslimani, N.; Modolo, G.; Wilden, A.; Sypula, M.; Vu, T. H.; Simonin, J. P., Highly efficient separation of actinides from lanthanides by a phenanthroline-derived bis-triazine ligand. J. Amer. Chem. Soc. 2011, 133 (33), 13093-13102. 
The Version of Record of this manuscript has been published and is available in SOLVENT EXTRACTION \& ION EXCHANGE 09 February 2021 https://www.tandfonline.com/doi/full/10.1080/07366299.2020.1831235

100. Whittaker, D. M.; Griffiths, T. L.; Helliwell, M.; Swinburne, A. M.; Natrajan, L. S.; Lewis, F. W.; Harwood, L. M.; Parry, S. A.; Sharrad, C. A., Lanthanide speciation in potential SANEX and GANEX actinide/lanthanide separations using tetra- $N$-donor extractants. Inorg. Chem. 2013, 52 (7), 3429-3444.

101. Afsar, A.; Harwood, L. M.; Hudson, M. J.; Westwood, J.; Geist, A., Effective separation of the actinides Am(III) and $\mathrm{Cm}$ (III) by electronic modulation of bis-(1,2,4-triazin-3-yl)phenanthrolines. Chem. Commun. 2015, 51 (27), 5860-5863.

102. Higginson, M. A.; Kyle, N. D.; Marsden, O. J.; Thompson, P.; Livens, F. R.; Heath, S. L., Synthesis of functionalised BTPhen derivatives - effects on solubility and americium extraction. Dalton Trans. 2015, 44 (37), $16547-16552$.

103. Edwards, A. C.; Wagner, C.; Geist, A.; Burton, N. A.; Sharrad, C. A.; Adams, R. W.; Pritchard, R. G.; Panak, P. J.; Whitehead, R. C.; Harwood, L. M., Exploring electronic effects on the partitioning of actinides(III) from lanthanides(III) using functionalised bis-triazinyl phenanthroline ligands. Dalton Trans. 2016, 45 (45), $18102-18112$.

104. Afsar, A.; Edwards, A. C.; Geist, A.; Harwood, L. M.; Hudson, M. J.; Westwood, J.; Whitehead, R. C., Effective separation of Am(III) from Cm(III) using modified BTPhen ligands. Heterocycles 2017, 95 (1), 575 586.

105. Edwards, A. C.; Geist, A.; Müllich, U.; Sharrad, C. A.; Pritchard, R. G.; Whitehead, R. C.; Harwood, L. M., Transition metal-free, visible-light mediated synthesis of 1,10-phenanthroline derived ligand systems. Chem. Commun. 2017, 53 (58), 8160-8163.

106. Lange, S.; Wilden, A.; Modolo, G.; Sadowski, F.; Gerdes, M.; Bosbach, D., Direct selective extraction of trivalent americium from PUREX raffinate using a combination of CyMe $\mathrm{C}_{4} \mathrm{BTPhen}$ and TEDGA-a feasibility study. Solvent Extr. Ion Exch. 2017, 35 (3), 161-173.

107. Williams, N. J.; Dehaudt, J.; Bryantsev, V. S.; Luo, H.; Abney, C. W.; Dai, S., Selective separation of americium from europium using 2,9-bis(triazine)-1,10-phenanthrolines in ionic liquids: a new twist on an old story. Chem. Commun. 2017, 53 (18), 2744-2747.

108. Distler, P.; Stamberg, K.; John, J.; Harwood, L. M.; Lewis, F. W., Modelling of the Am(III)-Cm(III) kinetic separation effect observed during metal ion extraction by bis-(1,2,4)-triazine ligands. Separ. Sci. Technol. 2018, 53 (2), 277-285.

109. Lewis, F. W.; Harwood, L. M.; Hudson, M. J.; Afsar, A.; Laventine, D. M.; Št’astná, K.; John, J.; Distler, P., Separation of the minor actinides americium(III) and curium(III) by hydrophobic and hydrophilic BTPhen ligands: exploiting differences in their rates of extraction and effective separations at equilibrium. Solvent Extr. Ion Exch. 2018, 36 (2), 115-135.

110. Reilly, S. D.; Su, J.; Keith, J. M.; Yang, P.; Batista, E. R.; Gaunt, A. J.; Harwood, L. M.; Hudson, M. J.; Lewis, F. W.; Scott, B. L.; Sharrad, C. A.; Whittaker, D. M., Plutonium coordination and redox chemistry with the $\mathrm{CyMe}_{4}-\mathrm{BTPhen}$ polydentate $N$-donor extractant ligand. Chem. Commun. 2018, 54 (89), 12582-12585.

111. Zsabka, P.; Hecke, K. V.; Wilden, A.; Modolo, G.; Verwerft, M.; Binnemans, K.; Cardinaels, T., Selective extraction of americium from curium and the lanthanides by the lipophilic ligand CyMe $4-\mathrm{BTPhen}$ dissolved in Aliquat-336 nitrate ionic liquid. Solvent Extr. Ion Exch. 2020, 38 (2), 194-211. 
The Version of Record of this manuscript has been published and is available in SOLVENT EXTRACTION \& ION EXCHANGE 09 February 2021 https://www.tandfonline.com/doi/full/10.1080/07366299.2020.1831235

112. Foreman, M. R. S. J.; Hudson, M. J.; Geist, A.; Madic, C.; Weigl, M., An investigation into the extraction of americium(III), lanthanides and D-block metals by 6,6 '-bis-(5,6-dipentyl-[1,2,4]triazin-3-yl)-[2,2 ']bipyridinyl (C5-BTBP). Solvent Extr. Ion Exch. 2005, 23 (5), 645-662.

113. Nilsson, M.; Ekberg, C.; Foreman, M. R. S.; Hudson, M.; Liljenzin, J. O.; Modolo, G.; Skarnemark, G., Separation of actinides(III) from lanthanides(III) in simulated nuclear waste streams using 6,6 '-bis-(5,6dipentyl-[1,2,4]triazin-3-yl)-[2,2 ']bipyridinyl (C5-BTBP) in cyclohexanone. Solvent Extr. Ion Exch. 2006, 24 (6), 823-843.

114. Traister, G. L.; Schilt, A. A., Water-soluble sulfonated chromogenic reagents of the ferroin type and determination of iron and copper in water, blood serum, and beer with the tetraammonium salt of 2,4-bis(5,6diphenyl-1,2,4-triazin-3-yl)pyridinetetrasulfonic acid. Anal. Chem. 1976, 48, 1216-1220.

115. Geist, A.; Müllich, U.; Magnusson, D.; Kaden, P.; Modolo, G.; Wilden, A.; Zevaco, T., Actinide(III)/lanthanide(III) separation via selective aqueous complexation of actinides(III) using a hydrophilic 2,6-bis(1,2,4-triazin-3-yl)-pyridine in nitric acid. Solvent Extr. Ion Exch. 2012, 30 (5), 433-444.

116. Ruff, C. M.; Müllich, U.; Geist, A.; Panak, P. J., Complexation of Cm(III) and Eu(III) with a hydrophilic 2,6-bis(1,2,4-triazin-3-yl)-pyridine studied by time-resolved laser fluorescence spectroscopy. Dalton Trans. 2012, 41, 14594-14602.

117. Nilsson, M.; Nash, K. L., Review article: a review of the development and operational characteristics of the TALSPEAK process. Solvent Extr. Ion Exch. 2007, 25 (6), 665-701.

118. Lewis, F. W.; Harwood, L. M.; Hudson, M. J.; Geist, A.; Kozhevnikov, V. N.; Distler, P.; John, J., Hydrophilic sulfonated bis-1,2,4-triazine ligands are highly effective reagents for separating actinides(III) from lanthanides(III) via selective formation of aqueous actinide complexes. Chem. Sci. 2015, 6 (8), $4812-4821$.

119. Sasaki, Y.; Sugo, Y.; Suzuki, S.; Tachimori, S., The novel extractants, diglycolamides, for the extraction of lanthanides and actinides in $\mathrm{HNO}_{3} / n$-dodecane system. Solvent Extr. Ion Exch. 2001, 19 (1), 91103.

120. Ansari, S. A.; Pathak, P.; Mohapatra, P. K.; Manchanda, V. K., Chemistry of diglycolamides: promising extractants for actinide partitioning. Chem. Rev. 2012, 112 (3), 1751-1772.

121. Whittaker, D.; Geist, A.; Modolo, G.; Taylor, R.; Sarsfield, M.; Wilden, A., Applications of diglycolamide based solvent extraction processes in spent nuclear fuel reprocessing, part 1: TODGA. Solvent Extr. Ion Exch. 2018, 36 (3), 223-256.

122. Wagner, C.; Müllich, U.; Geist, A.; Panak, P. J., Selective extraction of Am(III) from PUREX raffinate: the AmSel system. Solvent Extr. Ion Exch. 2016, 34 (2), 103-113.

123. Marie, C.; Kaufholz, P.; Vanel, V.; Duchesne, M.-T.; Russello, E.; Faroldi, F.; Baldini, L.; Casnati, A.; Wilden, A.; Modolo, G.; Miguirditchian, M., Development of a selective americium separation process using H4TPAEN as water-soluble stripping agent. Solvent Extr. Ion Exch. 2019, 37 (5), 313-327.

124. Wagner, C.; Müllich, U.; Geist, A.; Panak, P. J., TRLFS study on the complexation of Cm(III) and Eu(III) with $\mathrm{SO}_{3}-\mathrm{Ph}-\mathrm{BTBP}$. Dalton Trans. 2015, 44 (39), 17143-17151. 
125. Ekberg, C.; Löfström-Engdahl, E.; Aneheim, E.; Foreman, M. R. S.; Geist, A.; Lundberg, D.; Denecke, M.; Persson, I., The structures of CyMe4-BTBP complexes of americium(III) and europium(III) in solvents used in solvent extraction, explaining their separation properties. Dalton Trans. 2015, 44 (42), 18395-18402.

126. Kaufholz, P.; Modolo, G.; Wilden, A.; Sadowski, F.; Bosbach, D.; Wagner, C.; Geist, A.; Panak, P. J.; Lewis, F. W.; Harwood, L. M., Solvent extraction and fluorescence spectroscopic investigation of the selective Am(III) complexation with TS-BTPhen. Solvent Extr. Ion Exch. 2016, 34 (2), 126-140.

127. Steczek, Ł.; Rejnis, M.; Narbutt, J.; Charbonnel, M.-C.; Moisy, P., On the stoichiometry and stability of americium(III) complexes with a hydrophilic $\mathrm{SO}_{3}-\mathrm{Ph}-\mathrm{BTP}$ ligand, studied by liquid-liquid extraction. $J$. Radioanal. Nucl. Chem. 2016, 309 (2), 891-897.

128. Herdzik-Koniecko, I.; Wagner, C.; Trumm, M.; Müllich, U.; Schimmelpfennig, B.; Narbutt, J.; Geist, A.; Panak, P. J., Do An(III) and Ln(III) ions form heteroleptic complexes with diglycolamide and hydrophilic BT(B)P ligands in solvent extraction systems? A spectroscopic and DFT study. New J. Chem. 2019, 43 (16), 6314-6322.

129. Madic, C.; Hudson, M. J. High-level liquid waste partitioning by means of completely incinerable extractants; EUR 18038, European Commission, Luxembourg: 1998.

130. Lewis, F. W.; Harwood, L. M.; Hudson, M. J.; Núñez, A.; Galán, H.; Espartero, A. G., Synthesis and evaluation of a novel hydrophilic 6,6'-bis(1,2,4-triazin-3-yl)-2,2'-bipyridine ligand for separating actinide(III) from lanthanide(III). Synlett 2016, 27 (01), 1-5.

131. Mossini, E.; Macerata, E.; Wilden, A.; Kaufholz, P.; Modolo, G.; Iotti, N.; Casnati, A.; Geist, A.; Mariani, M., Optimization and single-stage centrifugal contactor experiments with the novel hydrophilic complexant PyTri-Diol for the i-SANEX process. Solvent Extr. Ion Exch. 2018, 36 (4), 373-386.

132. Weßling, P.; Trumm, M.; Macerata, E.; Ossola, A.; Mossini, E.; Gullo, M. C.; Arduini, A.; Casnati, A.; Mariani, M.; Adam, C.; Geist, A.; Panak, P. J., Activation of the aromatic core of 3,3'-(pyridine-2,6-diylbis(1H1,2,3-triazole-4,1-diyl))bis(propan-1-ol) — effects on extraction performance, stability constants, and basicity. Inorg. Chem. 2019, 58 (21), 14642-14651.

133. Edwards, A. C.; Mocilac, P.; Geist, A.; Harwood, L. M.; Sharrad, C. A.; Burton, N. A.; Whitehead, R. C.; Denecke, M. A., Hydrophilic 2,9-bis-triazolyl-1,10-phenanthroline ligands enable selective Am(III) separation: a step further towards sustainable nuclear energy. Chem. Commun. 2017, 53 (36), 5001-5004. 